\title{
Aptamers in Virology-A Consolidated Review of the Most Recent Advancements in Diagnosis and Therapy
}

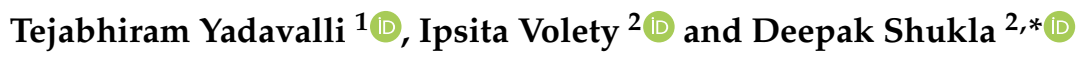 \\ 1 Department of Ophthalmology and Visual Sciences, University of Illinois at Chicago, Chicago, IL 60612, USA; \\ yteja@uic.edu \\ 2 Department of Microbiology and Immunology, University of Illinois at Chicago, Chicago, IL 60612, USA; \\ ivolet2@uic.edu \\ * Correspondence: dshukla@uic.edu
}

Citation: Yadavalli, T.; Volety, I.;

Shukla, D. Aptamers in Virology-A

Consolidated Review of the Most

Recent Advancements in Diagnosis and Therapy. Pharmaceutics 2021, 13, 1646. https://doi.org/10.3390/

pharmaceutics13101646

Academic Editors: Laura Cerchia and Simona Camorani

Received: 24 August 2021

Accepted: 1 October 2021

Published: 9 October 2021

Publisher's Note: MDPI stays neutral with regard to jurisdictional claims in published maps and institutional affiliations.

Copyright: (c) 2021 by the authors. Licensee MDPI, Basel, Switzerland. This article is an open access article distributed under the terms and conditions of the Creative Commons Attribution (CC BY) license (https:/ / creativecommons.org/licenses/by/ $4.0 /)$.

\begin{abstract}
The use of short oligonucleotide or peptide molecules as target-specific aptamers has recently garnered substantial attention in the field of the detection and treatment of viral infections. Based on their high affinity and high specificity to desired targets, their use is on the rise to replace antibodies for the detection of viruses and viral antigens. Furthermore, aptamers inhibit intracellular viral transcription and translation, in addition to restricting viral entry into host cells. This has opened up a plethora of new targets for the research and development of novel vaccines against viruses. Here, we discuss the advances made in aptamer technology for viral diagnosis and therapy in the past decade.
\end{abstract}

Keywords: aptamers; SELEX; diagnosis; therapy; viruses

\section{Introduction}

Aptamers are oligonucleotides or peptide molecules that bind specifically to a variety of targets, often inhibiting protein-protein interactions. While usually in the range of a hundred nucleotides, the most effective size is found to be around forty nucleotides. The term "aptamer" was first coined by the Szostak lab in the year 1990 and is derived from the Latin word "aptus", which means "to fit", and the Greek expression "meros," which means "part" [1]. While natural aptamers exist in riboswitches, they are commonly created through the SELEX process. The acronym "SELEX" stands for the systematic evolution of ligands by exponential enrichment and was coined by the Gold lab [2]. In SELEX, large libraries of random sequence pools $\left(10^{13}-10^{16}\right.$ copies) of ssRNA/ssDNA are progressively screened and selected, based on their ability to bind to the desired target, as well as their abilities to inhibit or activate various processes.

In this regard, various aptamers with applications ranging from catalysis to cancer therapy have come into existence. Their increased use and development have been noted for the detection and therapy of a variety of diseases, including cancer, diabetes, autoimmune diseases, bacterial and viral infections [3-7]. Of these, the diagnosis and therapy of viral infections via aptamers continue to generate great interest, owing to their immediate societal impact. Although the past decade has seen significant improvement in the field of immunology, pharmacology and microbiology, millions of people continue to be diagnosed with, treated for, suffer, and die every year from viral infections, especially due to the human immunodeficiency virus (HIV), hepatitis viruses, influenza viruses and herpes simplex virus (HSV), both type-1 and type- 2 .

Addressing this problem, aptamers have shown substantial efficacy in both diagnosis and treatment, with minimal or no side effects. In addition, aptamers do not encounter the issue of drug resistance that traditional antiviral medications inevitably run into. Owing to these exceptional qualities, numerous research papers on the diagnostic abilities, and both 
practical and potential therapeutic properties of aptamers have come into existence over the past two decades.

In this review article, we elucidate in detail the advancements that have been made in the past decade in the field of aptamers, specifically as they pertain to viral diagnosis and therapy. We also discuss the nature of these viral infections, by detailing their cellular and molecular machinery involved in causing infection. Furthermore, a comprehensive review of aptamers developed for each of these cellular mechanisms involved in viral infection is described. By reviewing the most recent forms of aptamer modifications implemented by researchers for improving their efficiency, we also delve into the recent, more advanced developments that have been reported in the field of aptamer detection and treatment for HIV, hepatitis, influenza and HSV.

\section{Human Immunodeficiency Virus (HIV)}

(HIV) is a member of the Retroviridae family, which causes acquired immunodeficiency syndrome (AIDS) in humans, a lethal disease that kills millions of people worldwide. The structure of HIV has been studied closely, and multiple treatment models have been presented in the past. However, with the advent of aptamer technology, scientists are adopting a multifaceted approach to curing this life-threatening disease that is safer than other alternatives. The molecular details of entry, including the added information on the structure of the virus, play a key role in designing the perfect aptamers for prevention, inhibition, and recovery from a viral infection. Here we briefly discuss the various receptors, proteins and organelles involved in viral infection, while highlighting those that have been used for the design of aptamers.

\subsection{HIV Structure and Entry}

HIV structure, cell binding and host cell entry were described in detail in a 2012 report [8]. HIV, like most other viruses, typically consists of an outer envelope and inner core proteins. The envelope consists of an outer lipid layer containing an envelope protein (Env) that is a heavily glycosylated trimer of the surface glycoproteins, the gp120 and gp41 heterodimers [9]. These proteins are believed to be critical for host cell binding during viral infection. Inside the lipid layer, a coat of matrix proteins termed "p17" is present between the outer envelope and inner core [10]. The inner core consists of the capsule protein "p24" that encapsulates single-stranded HIV RNA, HIV-reverse transcriptase (HIV-RT), protease, ribonuclease, and integrase [11].

HIV famously infects CD4 $4^{+}$lymphocytes; however, monocytes, macrophages, and dendritic cells (which are also $\mathrm{CD} 4^{+}$) have all been shown to get infected [11]. The process of virus-host binding involves the viral proteins gp120 and gp41, and the host receptors CD4, CCR5 and CXCR4. HIV is attracted toward the host cell; whether this is due to the negatively charged heparan sulfate proteoglycans on the host cell surface has been a matter of debate [8]. When in close range with host cells, HIV's gp120 interacts with the host's CD4 receptor, which is followed by an intricate series of steps involving the restructuring of viral gp120. Subsequently, in the host cell, CCR5/CXCR4 co-receptor binding occurs, which is thought to elicit the membrane fusion potential of viral Env, resulting in the successful binding of the virus to the host cell. The last step in the fusion process involves the hydrophobic gp 41 fusion peptide that tethers the viral and host membranes, forming a fusion pore [12].

The formation of the fusion pore assists in the entry of viral RNA and HIV-RT into the infected cell. The HIV-RT is responsible for the conversion of viral RNA into DNA that is consequently integrated into the host genome [13]. The viral genome consists of nine genes, of which gag, pol and env encode for the structural proteins required for the formation of new virus particles. These genes are transcribed and translated inside the host cell, resulting in the formation and eventual assembly of new virus particles that egress from the host cell to infect other cells [14]. A schematic illustration of HIV entry and egress can be seen in Figure 1. 


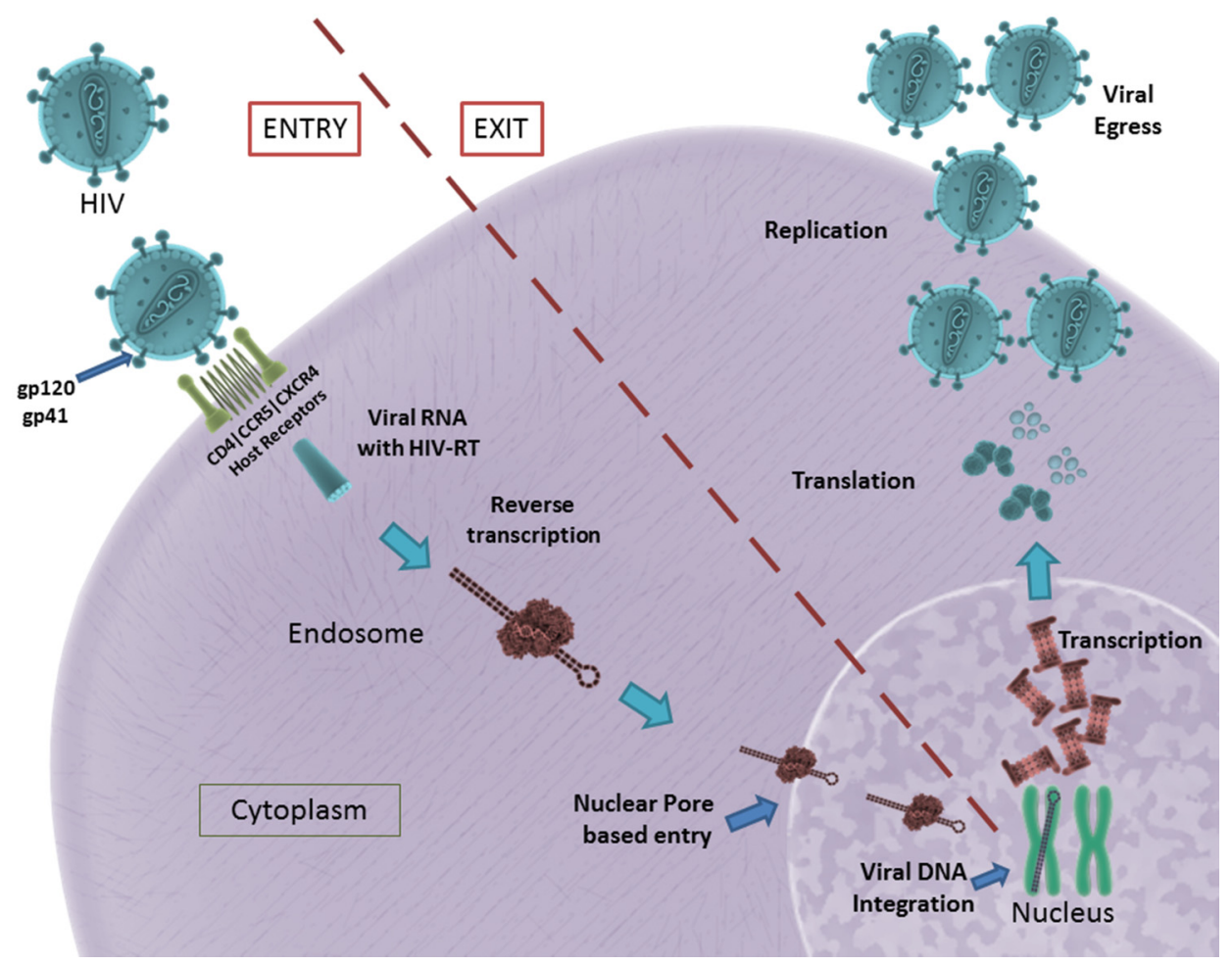

Figure 1. HIV entry and egress, as illustrated: Pictured are the important host receptors CD4, CCR5 and CXCR5. The viral glycoproteins gp120 and gp41 play an important role in attachment and entry; viral RNA is made and integrated into the host genome. After replication is facilitated, viral particles egress from the host cell. CC BY 4.0 license.

In summary, gp120, gp41, viral Env, HIV-RT, CD4 receptor, CCR5 and CXCR4 coreceptors play a significant role in HIV infection. They remain potential targets for the development of aptamers in the successful inhibition of HIV infection.

\subsection{Aptamers in Anti-HIV Therapy}

Owing to their conformational flexibility, RNA oligonucleotides have been used conventionally in the selection of aptamers for HIV therapy. However, multiple studies on DNA aptamers for the therapy/inhibition of productive HIV infection have also been described. In recent years, the focus was placed on developing aptamers for CD4, CCR5, gp120/gp41 and HIV-RT. Other notable aptamer targets include HIV-gag, thrombin, human cyclin T1, P24 antigen, aspartyl protease and nucleolin.

Small interfering RNAs (siRNA) have gained a reputation for disrupting undesirable pathways, in turn inhibiting viral infections. However, siRNAs innately lack the ability to target the desired site and need to be transported via a molecular carrier. In 2011, Zhou et al. reported RNA aptamers targeting HIV's viral gp120 [15]. By conjugating this 81nucleotide-long aptamer to siRNA, their team was able to demonstrate inhibitory action on HIV infections. The reported RNA aptamer had a dissociation rate constant $\left(\mathrm{K}_{\mathrm{d}}\right)$ of 47.91 $\mathrm{nM}$. Continuing this body of work, in 2013, the same group reported the in vivo delivery of the same aptamer-siRNA chimera using a chemically synthesized sticky bridge [16]. The sticky bridge facilitated the attachment of multiple siRNA chimeras to the same aptamer, as opposed to their previous model. They further reported the construction of three Dicer substrate siRNAs (DsiRNAs—-presently available through IDT, Inc. 1710 Commercial Park, Coralville, Iowa 52241, USA) onto the sticky bridge that facilitates the effective delivery of three different siRNAs to an infection site, thereby inhibiting multiple mRNA nodes in the HIV transcription process. In 2015, they developed a new aptamer, through live-cell SELEX and high-throughput next-generation sequencing, for the CCR5 co-receptor [17]. This aptamer, when combined with siRNA chimeras, was able to effectively block HIV 
entry and neutralize R5 virus infection through internalization. These reports have been consolidated into a book chapter, published by the group, that provides new insight into the development of next-generation therapeutics for HIV without the obstacle of drug resistance. Interestingly, in 2011, Wheeler et al. reported a siRNA-based gene knockdown mechanism to inhibit HIV infection in vitro and in tissue explants [18]. However, they used a CD4-binding aptamer, as opposed to a gp120-binding aptamer. Later in 2013, a clinical trial on humanized mice revealed the effectiveness of inhibiting transmission during sexual intercourse using the developed aptamer-chimera vaginal gel [19].

In 2012, Khati et al. showed significant modifications to an earlier-reported gp120 RNA aptamer named UCLA1, which was a shortened synthetic version of its predecessor [20]. This aptamer was reported to tightly bind to the HIV gp120 $\left(\mathrm{K}_{\mathrm{d}}=0.15 \mathrm{nM}\right)$ and elicited an $\mathrm{IC}_{50}$ (50\% inhibitory concentration) in the nanomolar range. The group reported the synergistic effect of the aptamer alongside gp41- and CD40-inhibiting antibodies. UCLA1based protection against HIV-mediated cardiomyopathy (HIVCM) was reported by [21]. They suggested that UCLA1 protects cardiomyocytes from caspase-mediated apoptosis directly by binding to HIV-1 and indirectly by preventing the infection of monocyte-derived macrophages. In 2015, the group reported a whole viral SELEX against HIV-1 subtype C to generate aptamers against all surface proteins of HIV [22]. The group not only isolated aptamers that bind to gp120 and gp41 but also some aptamers that bound to neither but that were able to elicit an inhibitory action on the HIV infection. Additional studies will need to be conducted to further understand the neutralizing properties of the isolated aptamers.

In the last decades, many synthetic G-rich oligonucleotides have been identified as promising anti-HIV candidate drugs $[23,24]$. Briefly, guanine-rich sequences often form hierarchical structures called G-quadruplexes which have unique target binding abilities (Figure 2).

The first G-quadruplex-forming oligonucleotide identified as a potent anti-HIV agent was the 8-mer phosphorothioate TTGGGGTT (ISIS 5320) [25], which exhibited the inhibition of HIV-1 at sub-micromolar concentrations. ISIS 5320 forms a tetramolecular parallel-stranded G-quadruplex, which is able to bind the V3 loop of the envelope glycoprotein gp120 and inhibit virus adsorption and cell fusion (Figure 1). Following these studies, Hotoda and coworkers have investigated a large number of G-rich oligonucleotides, some of which offer promising anti-HIV activity targeting HIV-1 entry through gp120 binding [26]. They selected the 6-mer d(5'TGGGAG3'), successively identified as "Hotoda's sequence" (Figure 2), as the lead sequence, which turned out to be active against HIV1 at submicromolar concentrations only when conjugated at the $5^{\prime}$-position with bulky aromatic moieties [27]. Subsequent detailed studies on the 6-mer d(5'TGGGAG3'), chosen as a useful model system, better elucidated the structure-activity relationships of G-quadruplex-forming oligonucleotides endowed with antiviral activity [28-30].

In 2014, Romanucci et al. prepared a number of novel analogs bearing different hydrophobic tails at the $5^{\prime}$-ends of Hotoda's sequence for the inhibition of HIV [31]. According to the study, the developed aptamers had low cytotoxicity, high anti-viral activity, good structural stability, and elevated resistance in human serum. Later, this group reported the development of a biomolecular G-quadruplex, with an HEG loop as an inversion of the polarity sites $3^{\prime}-3^{\prime}$ or $5^{\prime}-5^{\prime}$ and aromatic residues conjugated to $5^{\prime}$-end, which possessed greater thermal stability than its predecessor [32]. However, no increase or decrease in anti-HIV activity was reported. By chemically connecting the $3^{\prime}$ - and/or $5^{\prime}$-ends of four d(5'TGGGAG3') strands, thus obtaining bunchy oligonucleotides, unimolecular Gquadruplex structures with interesting anti-HIV properties were realized [33,34]. In 2012, Virgilio et al. gave a detailed report on the structure of the anti-HIV G-quadruplex-forming oligonucleotide TGGGAG and its analogs using various biochemical and structural studies [35]. They proposed the presence of an A tetrad in the G-quadruplex. 


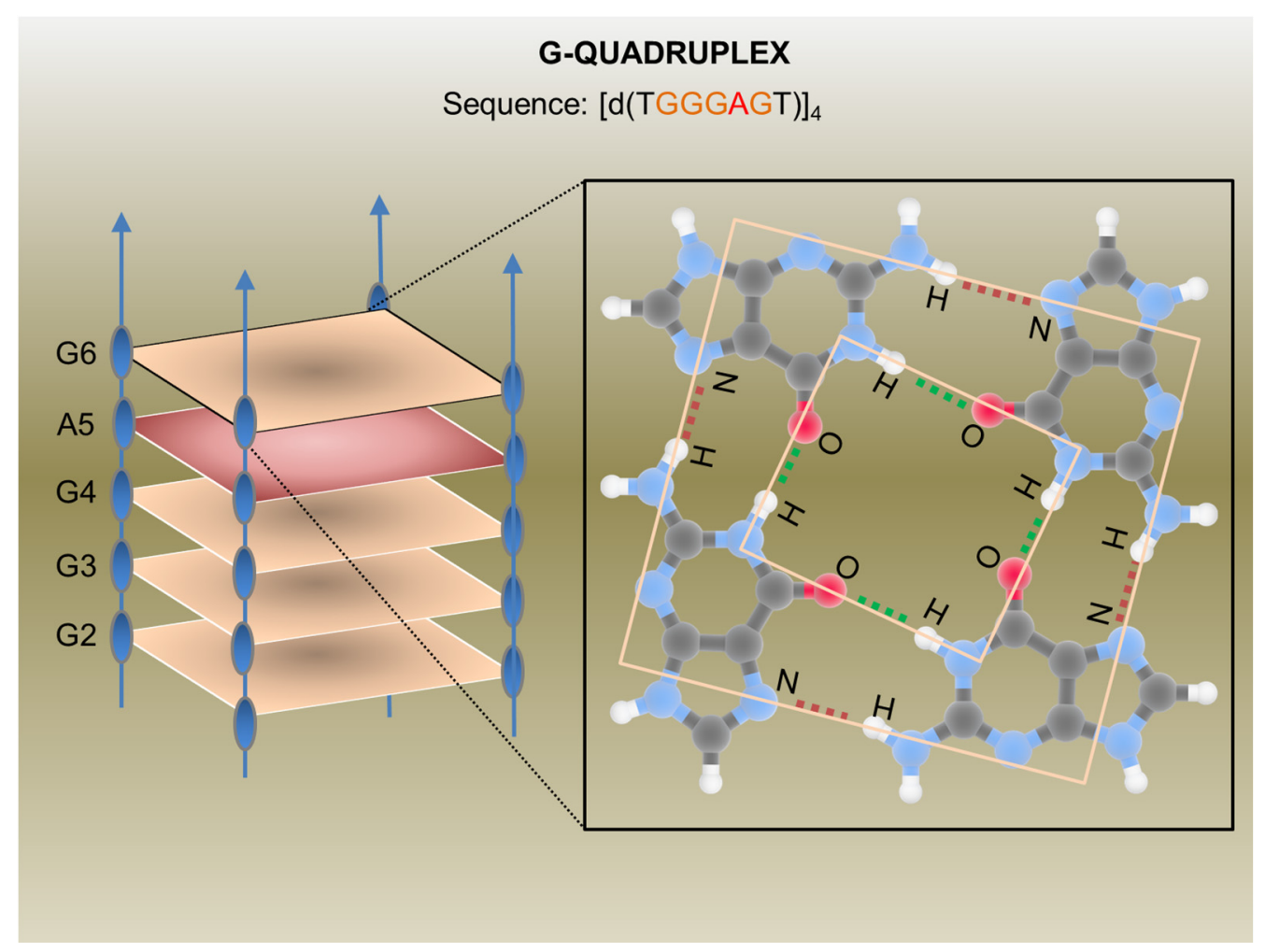

Figure 2. G-Quadruplex aptamer detailed in a report by Virgilio et al.: Schematic representation of the anti-HIV G-Quadruplex aptamers detailed in a report by Virgilio et al. [35] (on the left) and an example of a G-tetrad showing H-bonds (on the right). CC BY 4.0 license.

Although all the techniques and aptamers mentioned above are effective in reducing HIV infections, they do not elicit immunity in an individual who is being treated with them. In 2012, Burke et al. reported a robust model to inhibit HIV infection, where HIVRT-inhibiting RNA aptamers were produced intracellularly by modified cells [36]. They showed that aptamers that bind to the HIV-RT region could potentially inhibit productive replication and thus HIV infection (Figure 3). Using tertiary-stabilized hammerhead ribozymes with enhanced self-cleavage activity, aptamers were flanked into an expression cassette to be expressed in an infected cell. This significantly increased aptamer accumulation in viral and cellular compartments, neutralizing any HIV-RT present in the cell.

In 2013, the group showed a high-throughput sequencing (HTS)-based SELEX process in which different populations of RNA were evaluated for their binding capacity to the HIV1 virus [37]. HTS analysis was used to reveal the structural and functional details of various converged motifs that may otherwise be obscured by simpler consensus descriptions. HTS was used to distinguish 181 clusters determined to be capable of forming a conserved UCAA element in a non-pseudoknot motif [38]. This was established by screening 100 fulllength and 60 truncated aptamer transcripts for their F1Pk and F2Pk pseudoknot signature motifs. In 2014, this group reported a novel testing/screening model for RNA aptamers without the necessity of serial passages of HIV in aptamer-expressing cell lines [39]. The expression cassette mentioned earlier was used as a screening model, where a variety of aptamer sequences could be added to the cassette and later inserted into the cell line to help them express the same. The aptamer-expressing cell lines could then be tested for HIV-RT inhibition to screen for the most suitable aptamers. 


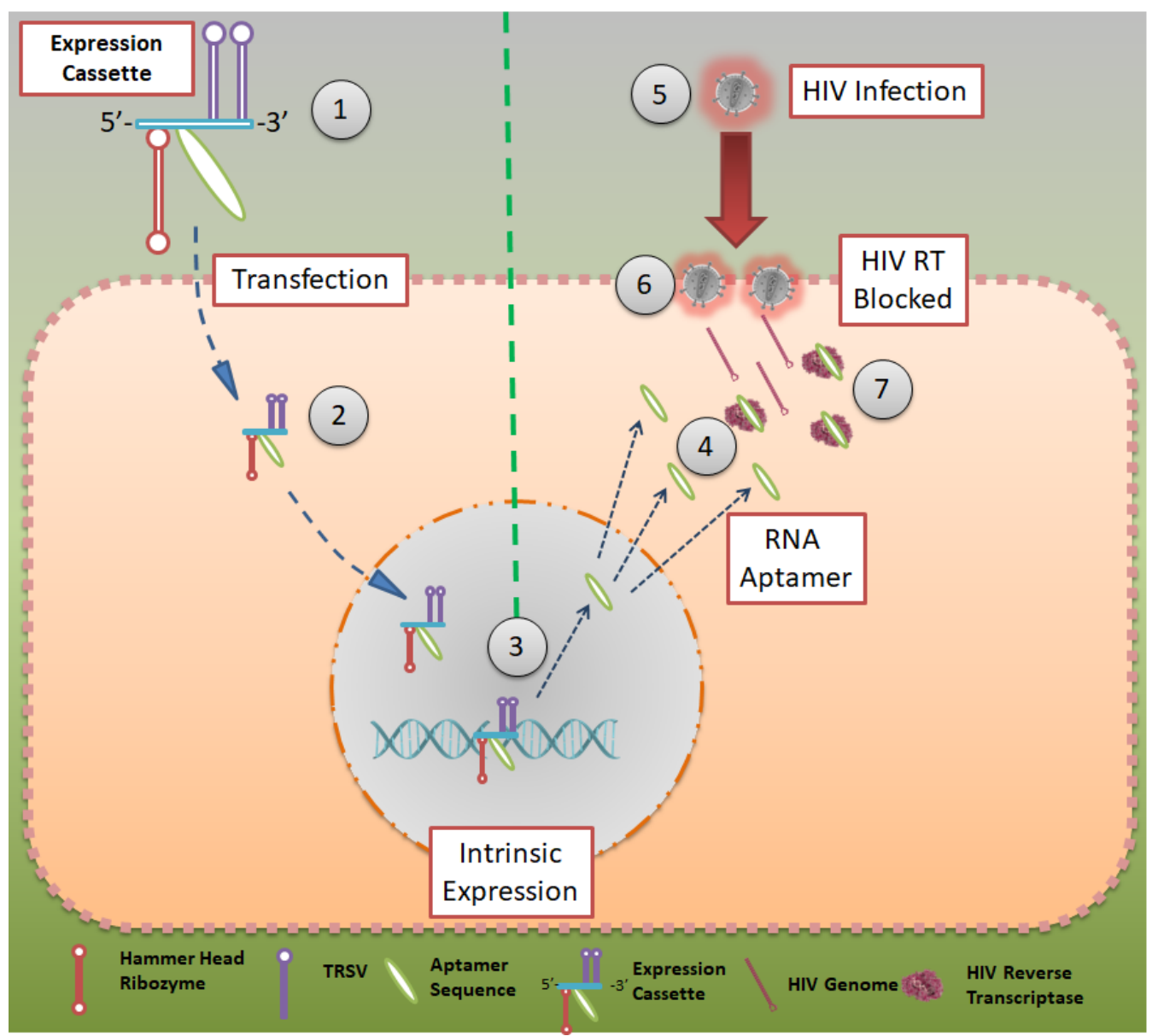

Figure 3. Aptamer expression cassette: Expression cassette modeled after HIV-RT that can be produced in intracellularly modified cells. Hammerhead ribozymes that are tertiary stabilized with self-cleavage activity may be expressed in infected cells. CC BY 4.0 license.

\subsection{Aptamers in HIV Detection}

Although non-conventional HIV-detection kits have not hit mainstream markets, they harbor an enormous potential to reduce the burden on diagnostic labs and change the landscape of the patient population visiting diagnostic labs if they become available. Aptamer technology represents one such way to improve the diagnostic capability regarding HIV infections.

Multiple models currently exist for the detection of HIV infections, of which the optical and fluorescent models remain popular. Rahim et al. [40] developed an aptamer for detection of the HIV trans-activator of the transcription (HIV-tat) peptide, which was then immobilized onto a diamond surface. The diamond surface formed part of a field emission transistor (FET) that was used for the potentiometric detection of HIV. The group showed that the detection range was in the picomolar range ( $1 \mathrm{pM}$ to $1 \mu \mathrm{g} / \mathrm{mL}$ ). The group followed this up with a report on the diamond aptamer FET in real sample scenarios, with detection at $1 \mathrm{nM}$ and a higher standard of reliability than current conventions [41].

In 2011, Liang et al. developed a direct visualization technique by conjugating fluorescent beacons to HIV-RT targeting aptamers [42]. Another fluorescent-based detection technique was developed by Kim et al. [43], in which double-stranded and dualanchored BHQ1-attached aptamers were conjugated to reduced graphene oxide nanosheets (Figure 4). Interferon- $\gamma$ was detected in the low picomolar range using this technique. This system was also tested for the detection of non-HIV targets, such as interleukin- 2 and tumor necrosis factor- $\alpha$. This module was able to rapidly quantify HIV infection in serum samples derived from HIV-infected individuals in less than $10 \mathrm{~min}$. 


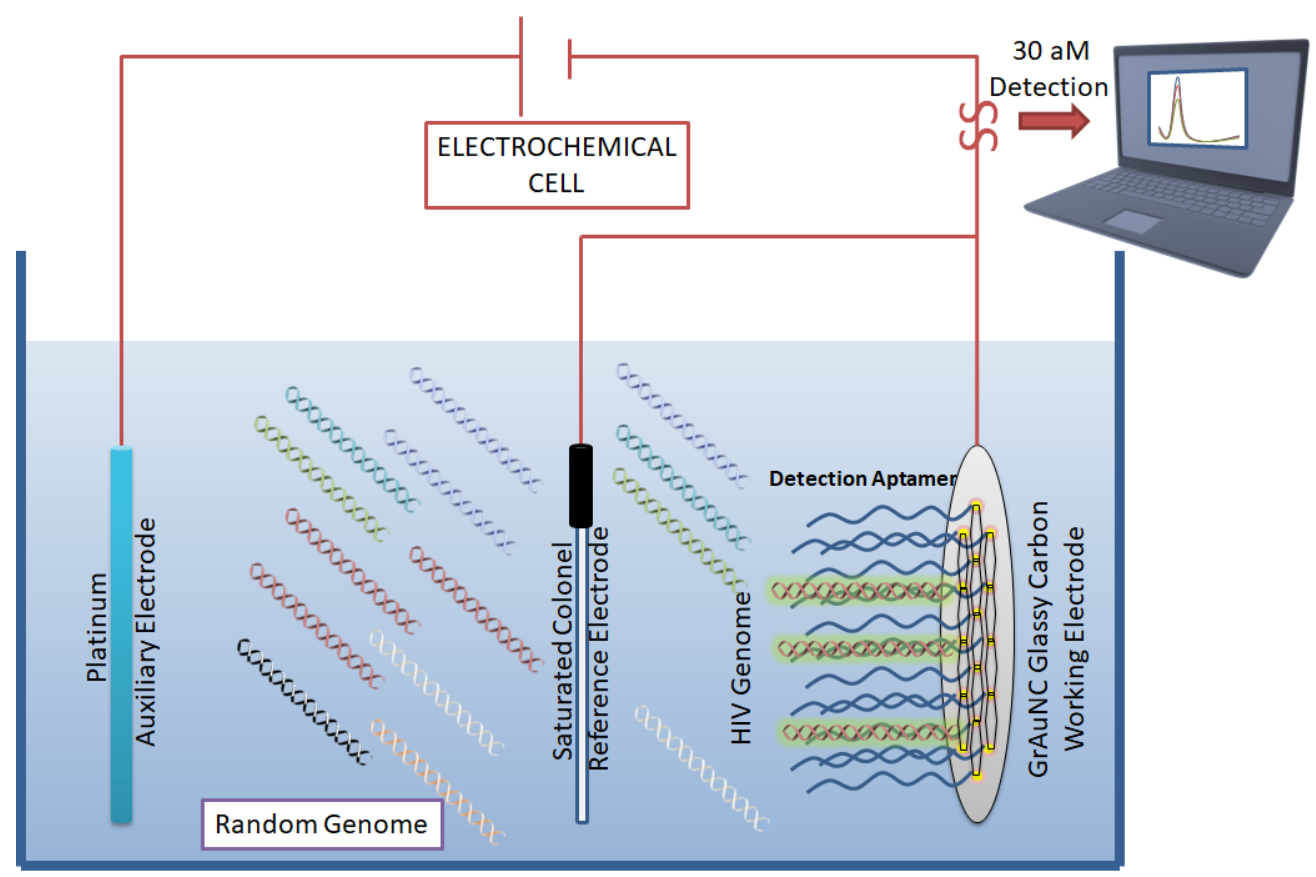

Figure 4. Aptamer-based biosensor for HIV detection: Graphene/gold nanocluster glass carbon electrode developed as a biosensor for the detection of HIV-DNA by Wang et al. They report the biosensor's potential for diagnostic analysis of human serum. CC BY 4.0 license.

In an ergonomic model, Niedzwiecki et al. demonstrated that by using nanopores that are smaller than the largest aptamer-target conjugate, one can screen for successful aptamers and determine their $\mathrm{K}_{\mathrm{d}}$ values simultaneously [44]. In this study, the authors report the label-free determination of $\mathrm{K}_{\mathrm{d}}$ between nucleocapsid protein 7 of $\mathrm{HIV}$ and the stem-loop 3 of an RNA aptamer. The nanopores were $6 \mathrm{~nm}$ in diameter and were made of silicon nitride. In a separate study, an atomic-force microscope (AFM) was used to carry out direct and label-free detection of gp120 HIV type-1 envelope glycoprotein as a target protein [45]. The method used anti-gp120 aptamers immobilized on the AFM chip to count gp120/aptamer complexes that formed on the chip surface. The detection limit was seen in the range of $0.8 \mathrm{nM}$ to $8 \mathrm{pM}$. However, the lowest detection limit of $30 \mathrm{aM}$ was reported by Wang et al. [46], who used a graphene/gold nanocluster modified glassy carbon electrode for the detection of HIV-DNA. They proposed that the developed biosensor was promising for the diagnostic analysis of human serum (Figure 4).

Various other aptamers that bind to the CCR5 and gp41 regions have been reported and are noted in Table A1 [39,47-71].

\section{Hepatitis Virus (HBV, HCV)}

Viral hepatitis is caused by 5 well-known viruses, namely hepatitis A virus (HAV), hepatitis $B$ virus (HBV), hepatitis $C$ virus (HCV), hepatitis D virus (HDV) and hepatitis $E$ virus (HEV). Of these, $\mathrm{HBV}$ and $\mathrm{HCV}$ are the most studied with respect to their structure and mode of entry into a host cell. Despite the similarity in their names, HBV and HCV belong to two different virus families, with profoundly distinct features.

\subsection{HBV Structure and Lifecycle}

HBV belongs to the Hepadnavirus family, which consists of a spherical, partially double-stranded DNA inside an icosahedral nucleocapsid core protein. Similar to HIV, HBV contains DNA polymerase, which has reverse transcriptase activity. The outer lipid membrane consists of three kinds of HBV surface antigens (HBsAg) - "S", " $\mathrm{M}$ " and "L" HBsAg, which are important for virus-cell fusion by targeting the surface receptors of the host cell $[72,73]$. 
HBV attaches to host hepatocytes through the sodium/bile acid co-transporting peptide SLC10A1, with the help of HBsAg. This is followed by a clathrin-mediated endocytosis step that allows for the internalization of the virus. HBV DNA and core proteins are then released into the cytoplasm and are then transported by the cellular machinery into the nucleus, through a nuclear pore [74].

HBV DNA undergoes a transformation from partially double-stranded to a covalently closed circular double-stranded DNA (cccdsDNA) inside the nucleus. At this stage, cccdsDNA is converted into a long mRNA using host RNA polymerase, which is then transported into the cytoplasm for translation. The viral mRNA not only codes for core proteins and other structural components but also for the genome of the newly born virus. The virion P protein, which is known to be synonymous with reverse transcriptase, is responsible for the synthesis of viral DNA [75].

\subsection{HCV Structure and Lifecycle}

Unlike HBV, HCV is a positive-strand RNA virus that belongs to the Flaviviridae family. It is known to showcase two surface glycoproteins, "E1" and "E2", on its envelope that envelop a single strand of the viral RNA, encompassed by core proteins [76]. The complete $\mathrm{HCV}$ lifecycle is depicted in Figure 5.

$\mathrm{HCV}$ circulates in the blood, where it encounters the basolateral surface of hepatocytes. The surface E1 and E2 glycoproteins attach to the surface receptors, which assist in the entry of the virus into the cell. Evidence is also available that HCV hybridizes with lipids and cholesterol in the blood to form "lipo-viral particles" (LVP) that give HCV immunity against antibody neutralization before entering the host cell [77]. Five surface receptors, namely, CD81, scavenger receptor class B member 1 (SRB1), claudin 1 (CLDN1), occludin (OCLN) and the cholesterol absorption receptor Niemann-Pick C1-like 1 (NPC1L1) are required for suitable attachment of the virus to the cell surface. $\mathrm{HCV}$ is known to interact with low-density lipoprotein receptors (LDLR) and the glycosaminoglycans present on the heparan sulfate proteoglycans (HSPG), which remove the lipid components from the LVP [77]. This induces structural changes to E2, enabling CD81 binding. Post-CD81 binding, the HCV particle then moves laterally to the cell-cell contact, where CD81 interacts with CLDN1. Similar to HBV, HCV is then internalized by clathrin-mediated endocytosis, where the endosome contains a low-pH compartment [78]. This prompts the fusion of the viral capsid via NPC1L1 and OCLN, releasing viral RNA into the cytoplasm [79].

Via translation of the viral RNA, a polyprotein is produced that is cleaved by both viral and cellular proteases. Each polypeptide chain of the polyprotein encodes for structural proteins, core proteins, glycoproteins and non-structural (NS) proteins. Non-structural proteins, namely, p7, NS2, NS3, NS4A, NS5A and NS5B, are not incorporated into the virus but help coordinate HCV replication, viral RNA synthesis and the assembly of virus particles. HCV particles are formed by budding into the endoplasmic reticulum (ER), followed by the sequential assembly of glycoproteins, core proteins and the viral RNA. It has been shown that post-assembly, HCV particles follow a series of subcellular compartments (secretory pathway) to the exit cells [80].

\subsection{Aptamers for Hepatitis Virus Therapy}

From the collected data, it was evident that DNA aptamers were predominantly used for the treatment of HBV and HCV. It is also interesting to note that most of the research conducted in recent years is an extension of previously reported aptamers, as opposed to novel oligonucleotide sequences. This could be due to well-defined, commercially available aptamers through reputed sources. It is also worth noting that studies have predominantly concentrated on HCV diagnosis and therapy rather than HBV or other hepatitis viruses.

In 2011, Feng et al. demonstrated a proof-of-concept by constructing an RNA aptamer that was able to bind and suppress the HBV P protein [81]. As mentioned previously, the HBV P protein is crucial for viral RNA replication and the subsequent progeny. In this study, they reported a first-in-class inhibitor of viral RNA replication through a 29- 
nucleotide RNA aptamer that was screened with the SELEX process using a recombinant truncated HBV P protein. A review article, detailing the prospects of inhibiting the posttranscriptional regulation of $\mathrm{HBV}$ genes, by Chen et al. explains the same finding in further detail [82]. In 2014, Zhang et al. reported a DNA aptamer that was commercially selected and synthesized using the SELEX process against the HBV core protein [83]. The aptamer showed the complete inhibition of HBV viruses in HepG2.2.15 cell lines, by disrupting the assembly of the viruses. In 2015, Orabi et al. reported the development of DNA aptamers that specifically bind to HBV capsid but not to the isoleucine 126A matrix domain [84]. This was achieved by targeting aptamers to the capsid proteins while counter-selecting them against isoleucine 126A. Although the developed aptamers were able to bind to the viral capsid, their inhibitory action was low. The low half-life time $(2 \mathrm{~h})$ in cells was determined to be the limiting factor influencing the incomplete inhibition.

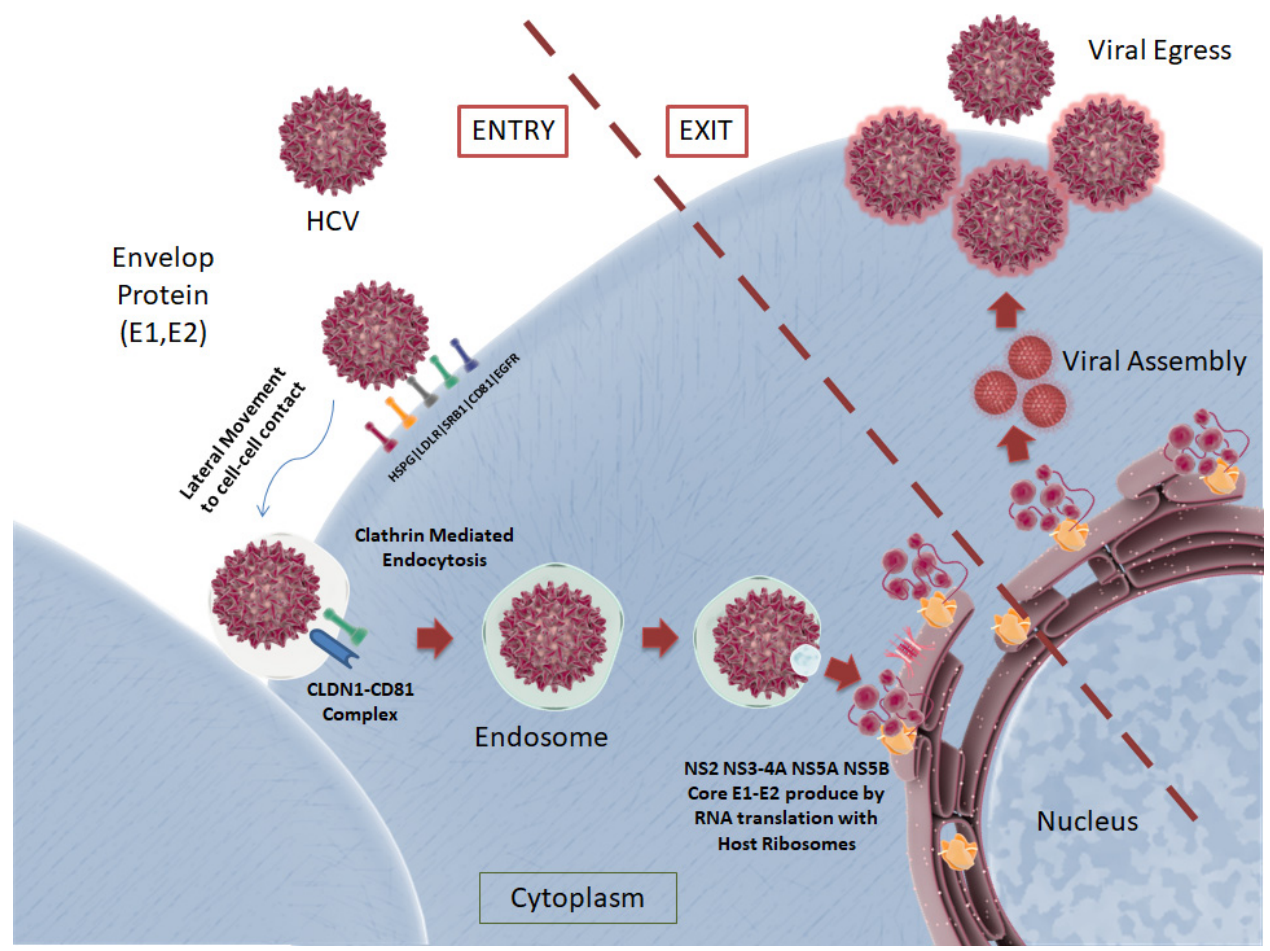

Figure 5. The HCV lifecycle depicted: Two surface proteins, E1 and E2, present on the viral envelope play a role in the attachment to host cell receptors LDLR, HSPG, SRB1, CD81 and EGFR. RNA replication with host ribosomes takes place, followed by viral particle assembly and egress. CC BY 4.0 license.

Berzal-Herranz et al. demonstrated the development of RNA aptamers for the inhibition of the cis-acting replication element (CRE) located on the $3^{\prime}$ end of the NS5A coding region [85]. They showed an $80 \%$ reduction in viral infection in Huh-7 cell cultures. They also developed an RNA aptamer for the inhibition of the highly conserved internal ribosome entry site (IRES) on the $5^{\prime}$ untranslatable region of the HCV genome [86]. They proposed that targeting molecules to these regions would completely disable the production of viral proteins, as viral translation greatly differs from cellular translation processes. In 2013, the same group developed RNA aptamers that were able to target conserved regions of the viral RNA which coded for the NS5A RNA polymerase [87]. They identified multiple aptamers that could inhibit viral replication by approximately $50 \%$ at concentrations close to $0.5 \mu \mathrm{M}$.

A study by Lee et al. reported the selection of RNA aptamers and their consequent $2^{\prime}$ hydroxyl, 2'-fluoropyrimidine modification against the NS5B replicase $[88,89]$. By blocking this enzyme, the study effectively showed the inhibition of HBV viral replication without 
any damaging off-target effects or escaping mutant generation. In 2015, this aptamer was further modified by cholesterol conjugation, resulting in better bioavailability in a mouse model [90]. A review article [91] by the group reports various other aptamers that are available and the prospects of nucleic acid-based therapeutics for HCV.

In 2013, Yang et al. reported the production of aptamers that target surface E1 and E2 proteins of HCV [92]. Purified forms of the E1 and E2 proteins were used as SELEX targets to generate the desired aptamers. The group suggested that these aptamers were able to decrease infection through the inhibition of the virus particles that bind to host cells. In 2015, Delaviz et al. also reported the development of DNA aptamers against E1 and E2 surface proteins [93]. These aptamers were conjugated to magnetic nanoparticles and, through magnetic separation, productive infection in the blood serum was selectively isolated and removed (Figure 6).

\subsection{Aptamers for Hepatitis Virus Diagnosis}

A competitive binding assay using RNA aptamers was developed by Suh et al. [94] that helped them to detect the HBV surface antigen in samples without any pre-treatment. They claim that their protocol is 40 times more sensitive than the commercially available Abbott Architect assay for HBV surface antigen detection. Similarly, in 2015, Xi et al. reported a chemiluminescence assay with a detection limit of $0.1 \mathrm{ng} / \mathrm{L}$ for the detection of the HBV surface antigen [95], using DNA aptamers.

Using an Octet optical biosensor, Roh et al. were able to detect the viral NS5B protein with the help of RNA aptamers [96]. The biotinylated RNA oligonucleotide optical biosensor was able to detect target proteins as low as $700 \mathrm{pg} / \mathrm{mL}$. Another rapid yet specific lateral-flow strip for the detection of HCV was developed by Wang et al. using a DNA aptamer [97]. The aptamer was able to target HCV core proteins with a detection limit of close to $10 \mathrm{pg} / \mathrm{mL}$. Similarly, an enzyme-linked aptamer-sorbent assay (ELASA) for the detection of the HCV E2 protein was developed by Park et al., which had a detection limit of $0.8 \mathrm{nM}$ [98]. A full list of aptamer for hepatitis virus diagnosis and therapy are listed in Table A2 [99-110].

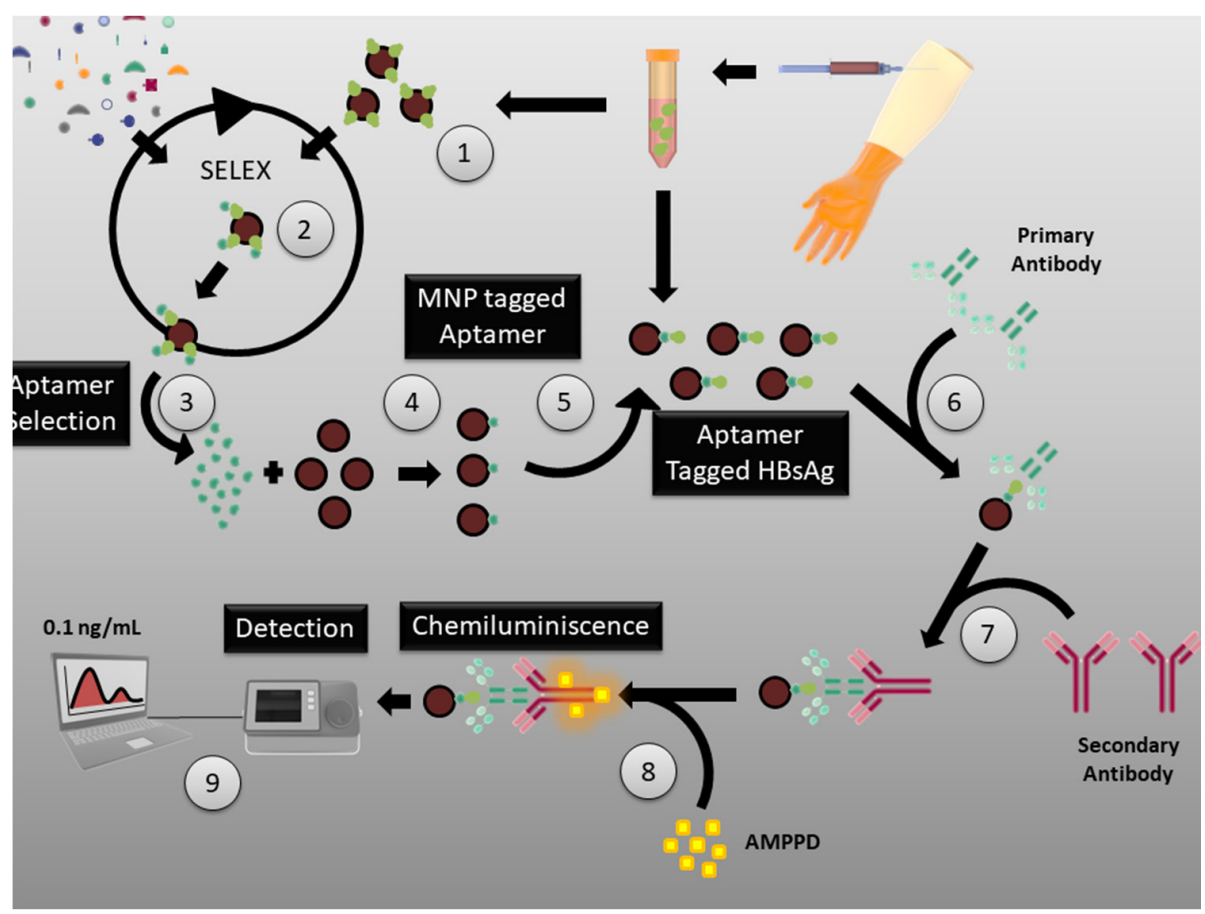

Figure 6. SELEX process for the generation of aptamers against HCV: E1 and E2 proteins of HCV used as targets in SELEX to generate aptamers against virus particles that bind to host cells. CC BY 4.0 license. 


\section{Influenza Virus}

Influenza viruses belong to the Orthomyxoviridae family and are sub-divided into three major types: influenza types $\mathrm{A}, \mathrm{B}$ and $\mathrm{C}$ viruses. Of these, $\mathrm{A}$ and $\mathrm{B}$ primarily cause infections in humans and are known to cause flu pandemics around the world. All three influenza virus types have been thoroughly studied and their life cycles are well documented. To address the significant public-health cost and threat caused by these viruses, aptamer technology has seen rapid progress to provide cost-effective solutions to influenza infections. Here, we will review the structure and life cycle of the influenzaA virus and its sub-types, while highlighting some key anti-influenza aptamers. The information regarding the structure and lifecycle of the influenza-A virus can be found in much greater detail in the Elsevier article report on rapid-reference influenza [111].

\subsection{Structure and Lifecycle of Influenza-A Virus}

The influenza-A virus is characterized by the presence of two major surface glycoproteins, namely, "hemagglutinin" (HA) and "neuraminidase" (NA). There are 16 HA subtypes and 9 NA subtypes. Based on the nature of these proteins, various influenza-A virus subtypes have been discovered and, of those, only H1N1, H2N2 and H3N2 viruses are considered mortally harmful to humans. The complete lifecycle of a typical influenza virus is depicted in Figure 7.

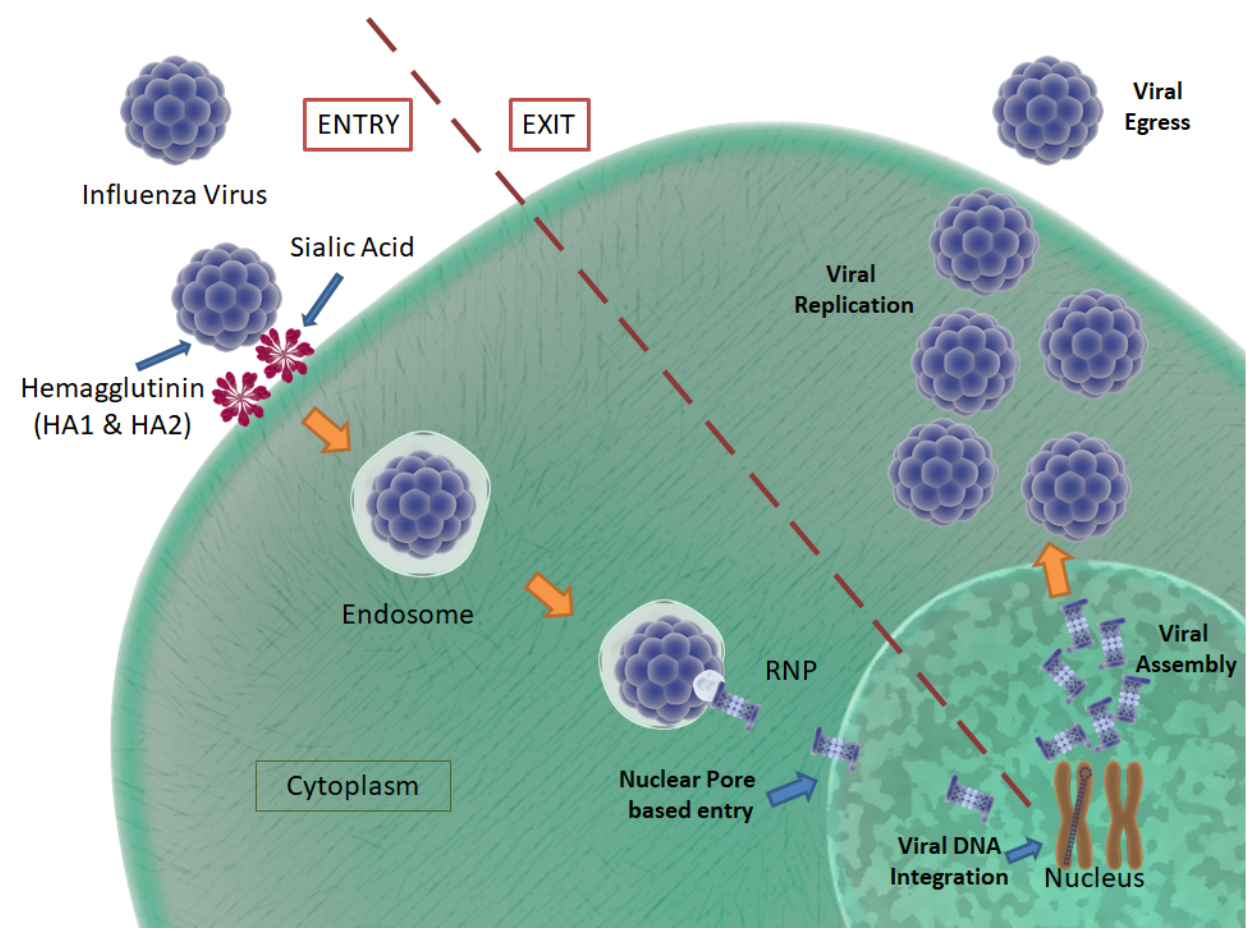

Figure 7. Influenza virus life cycle: Influenza virus entry, integration, assembly and egress, as pictured. The viral envelope is composed of HA and NA proteins. The HA proteins, HA1 and HA2, play a role in the fusion process of the virus T host cell. NA cleaves bonds between the host surface receptors and assists in viral egress. CC BY 4.0 license.

The influenza virus consists of 8 negative-sense RNA segments, nucleoprotein, and polymerase inside a lipid membrane envelope, which is coated by M1 proteins on the inner surface and M2 proteins on the outer surface. As mentioned earlier, the envelope is also encompassed by rod-shaped HA and mushroom-shaped NA, present on the outer surface in a 4:1 composition ratio. HA consists of two major subunits, namely, HA1 and HA2, which are bound by disulfide bonds. The HA2 subunit consists of a conserved hydrophobic amino acid chain, known as a fusion-peptide, which conducts the membrane fusion process 
between the virus and host cells. Conversely, NA has enzymatic activity that cleaves the bonds between surface receptors and the virus, assisting in viral egress [112].

The influenza virus enters a host body through both the enteral and parenteral routes. When it encounters the epithelial cells of the mucous membrane, the virus attaches to sialic acid residues, via HA binding [113]. Post-binding, receptor-mediated endocytosis is activated that allows the uptake of the virus into the host cell. The viruses are encapsulated in the host plasma membrane in the form of endosomes, where the virus fuses with the endosome to attain access to the host cell's cytoplasm. As is synonymous with HCV, the low $\mathrm{pH}$ of the endosomal compartment is known to cause a fusion process between the viral envelope and the endosomal membrane. Here, HA2 plays a vital role in binding with the endosomal membrane, eventually fusing both together to create an endosomal pore through which the viral RNA, nucleoprotein and polymerase are released into the cytosol [114].

The viral genome traverses through the cytosol to enter the host nucleus, where the viral nucleoprotein transcriptase (consisting of PB1, PB2 and PA) converts the negativesense viral RNA to messenger RNA (mRNA) [112]. The mRNA is then transported into the cytosol, where it is transcribed to form structural proteins, such as HA, NA and M2. The mRNA also serves as the template for the creation of negative-sense viral RNA for the new virus particles. Viral proteins are translocated to the endoplasmic reticulum, where they are glycosylated before they are carried to the Golgi apparatus. Here, the M2 protein has been shown to block premature HA unfolding due to the acidic nature of the trans-Golgi network [111]. Viral proteins and the genome are then transported to the host plasma membrane, starting the budding process. After the completion of the budding process, the viruses are still attached to the plasma membrane through the binding of sialic acid residues. They are enzymatically cleaved by NA to dissociate them from the plasma membrane, releasing new virus particles into the apical side of the epithelial cells [115].

\subsection{Aptamers for the Treatment of the Influenza Virus}

Most studies done on developing aptamers against influenza viruses have concentrated on H1N1, H3N2, H5N1, H5N2, H9N2, and PERTH sub-strains. It is worth noting that DNA aptamers are more commonly used in recent years, as opposed to RNA aptamers. The common target in SELEX (for anti-influenza aptamer isolation) was hemagglutinin, specific for the influenza virus.

RNA aptamers against the hemagglutinin of the H1N1 virus were developed by Gopinath S.C.B. and Kumar P.K.R. in 2013 [116]. The aptamers showed significantly low $\mathrm{K}_{\mathrm{d}}$ values, which was indicative of their use as effective inhibitors of viral entry. Musafia et al. reported a DNA aptamer-BV02 — that had high specificity toward hemagglutinin [117]. They developed a quantitative structure-activity relationship (QSAR) tool for the effective determination of 2D structural motifs of the target and aptamers. This helped them determine that the activity/binding affinity of the aptamer was less specific to the sequence and showed more specificity to the structure. Using the QSAR tool, they were able to predict with $89 \%$ accuracy the binding affinity between a known aptamer and the desired target. Wongphatcharachai et al. developed neutralizing DNA aptamers against the H3N2 virus by targeting the $\mathrm{H} 3$ hemagglutinin [118]. The strongest contender for binding had the lowest $K_{d}$ of $3.7 \mathrm{nM}$ and was able to bind to the virus in serum samples extracted from clinical patients.

In 2013, a G-Quadruplex-based DNA aptamer against the NS-1 protein of the influenza H5N1 virus was developed [119]. While NS-1 inhibits the host's innate immune response, the DNA aptamer was able to induce the production of IFN- $\beta$, leading to the effective suppression of the NS-1 protein and viral replication, without affecting host cell viability. An RNA aptamer against the highly pathogenic avian influenza H5N1 virus was developed by Suenaga and Kumar [120]. This aptamer showed selective binding to viral H5 rather than H7 hemagglutinins. In a 2015 study, DNA aptamers were developed against the H5N1 PA subunit, which actively takes part in RNA polymerase and endonuclease activity [121]. 
These aptamers have low $K_{d}$ values as well as an IC50 concentration as low as $10 \mathrm{nM}$, making them very exciting additions to the field.

Two RNA aptamer studies conducted in 2014, targeting the hemagglutinin of the H5N2 virus, were reported by Kim et al. [122,123]. They reported aptamers that bind to the glycosylated HA1 domain of hemagglutinin and showed complete anti-viral activity with no detected reduction in cell viability. These two DNA aptamers, developed by Choi et al. [124] and Zhang et al. [125], showed potent inhibition of the virus in vitro against the H9N2 virus. While both the groups targeted the HA component of the virus, Zhang et al. used capillary electrophoresis-based SELEX for the selection of successful aptamers.

\subsection{Aptamers for the Detection of the Influenza Virus}

Detection of the influenza virus during the past five years has predominantly concentrated on the H5N1 virus. This can be attributed to the rising numbers of reported deaths caused by the highly pathogenic H5N1 virus in many parts of Asia and the Middle East. Avian influenza is still a persistent public health threat in many Asian countries.

Of the various sensors used for the detection of the H5N1 virus, electrochemical impedance-based sensors were the most used. This could be due to the ease of building one in a small amount of time. Lui et al. have reported multiple studies on the detection of the H5N1 virus [126-131]. While earlier reports by the group studied the process of SELEX for developing aptamers against hemagglutinin [126-129], recent updates have reported the use of the entire virus as a target $[130,131]$.

All the studies used DNA as the nucleic acid of choice. Using a surface plasmon resonance-based setup (SPR), biotinylated aptamers were used for the rapid detection of a virus. The detection limit in this report was noted as 0.128 hemagglutinin units (HAU). A similar study that used quartz crystal monitors instead of an SPR setup showed a lower detection limit of $0.0128 \mathrm{HAU}$. In a different study, an SPR-based SELEX process was used to elucidate the binding affinity of the aptamer in targeting the hemagglutinin of H5N1. The group proposed this technique as a potential novel system for the screening of aptamers. The same group showed a detection limit of $0.0004 \mathrm{HAU}$, using an enzymatic sandwich assay with concanavalin A, glucose oxidase, and Au nanoparticles.

Using the models described above, another study described a detection methodology that used an aptamer bio-nanogate that could selectively respond to target molecules and control enzymatic reactions for electrochemical measurements. The setup had a detection limit of 2-9 HAU and the capacity to sense within $1 \mathrm{~h}$ of activation. In a follow-up report, the same group revealed a microfluidic setup, consisting of biotinylated aptamers that could sense H5N1 viruses, with a detection limit of 0.0128 HAU within 30 min of activation. In 2011, Liu et al. revealed an electrochemical sensing assay with a detection limit that was the lowest of all the detection setups mentioned earlier [132]. The multi-wall carbon nanotubes, polypyrrole nanowires, gold nanoparticles and DNA aptamer-based setup had a detection limit of $43 \mathrm{pM}$ for H5N1-specific gene sequences. In an article by Diba et al., this detection limit was exceeded by demonstrating detection up to $100 \mathrm{fM}$ using an amperometric sensor [133]. The sensor relies on the formation of a complex consisting of gold nanoparticles and the DNA aptamer/H5N1/antiH5N1-alkaline phosphatase. In contrast to these developments in aptamer technology, a glycan-based impedimetric sensor utilized in 2016 had a detection limit of 5aM-claiming to be the most sensitive detection model, compared to current antibody or aptamer-based detection systems [134].

A G-Quadruplex DNA aptamer-based SPR sensor was also reported in 2015, which was able to detect H1N1 hemagglutinin with a detection limit in the $\mathrm{nM}$ range [110]. It was the only study that reported a G-Quadruplex DNA aptamer for H1N1 influenza sensing/detection.

In 2011, Negri et al. used a surface-enhanced Raman (SERS)-based aptamer assay for the detection of viral nucleoproteins [135]. The study showed a detection limit of 0.1 $\mu \mathrm{g} / \mathrm{mL}$, using a 22-nucleotide-long DNA aptamer. The same group demonstrated a direct optical detection method of viral nucleoproteins, using a multi-variant anti-influenza ap- 
tamer [136]. This SERS-based method had a detection limit of $1 \mu \mathrm{g} / \mathrm{mL}$ and was validated by atomic force microscopy studies. A full list of aptamers that help in the diagnosis and therapy of influenza virus infection are listed in Table A3 [134,137-146].

\section{Herpes Simplex Virus (HSV)}

Herpes simplex virus (HSV) is a double-stranded DNA virus that belongs to the Herpesviridae family. HSV has two serotypes, namely, HSV-1 and HSV-2, which predominantly cause orofacial and genital lesions, respectively. It is estimated that upwards of $70 \%$ of American adults suffer from HSV infection, and it is the main cause of infectious blindness in the USA. HSV is infamous for recurring infections leading to herpetic lesion outbreaks, owing to a significant decrease in host immunity or high stress levels, which makes the virus a serious global public health threat [147-149].

\subsection{HSV Structure and Lifecycle}

HSV consists of single linear double-stranded DNA, enclosed within an icosahedral capsid that consists of the four capsid proteins-VP5, VP26, VP23, and VP19C [150]. The capsid is surrounded by a protein-rich layer containing tegument proteins, which are known to regulate the transcription of immediate-entry genes. The most documented tegument proteins include VP16 and VP22, which regulate and stabilize viral transcription and proteins, respectively $[151,152]$. The tegument proteins are encapsulated inside a triple-layered lipid membrane that forms the envelope for the virus. The viral envelope is covered with four distinct surface glycoproteins, namely, $\mathrm{gB}, \mathrm{gC}, \mathrm{gD}$ and a $\mathrm{gH} / \mathrm{gL}$ heterodimer $[153,154]$. These surface glycoproteins facilitate the attachment of the virus to host cells and the subsequent fusion process. A consolidated depiction of the HSV lifecycle is represented in Figure 8.

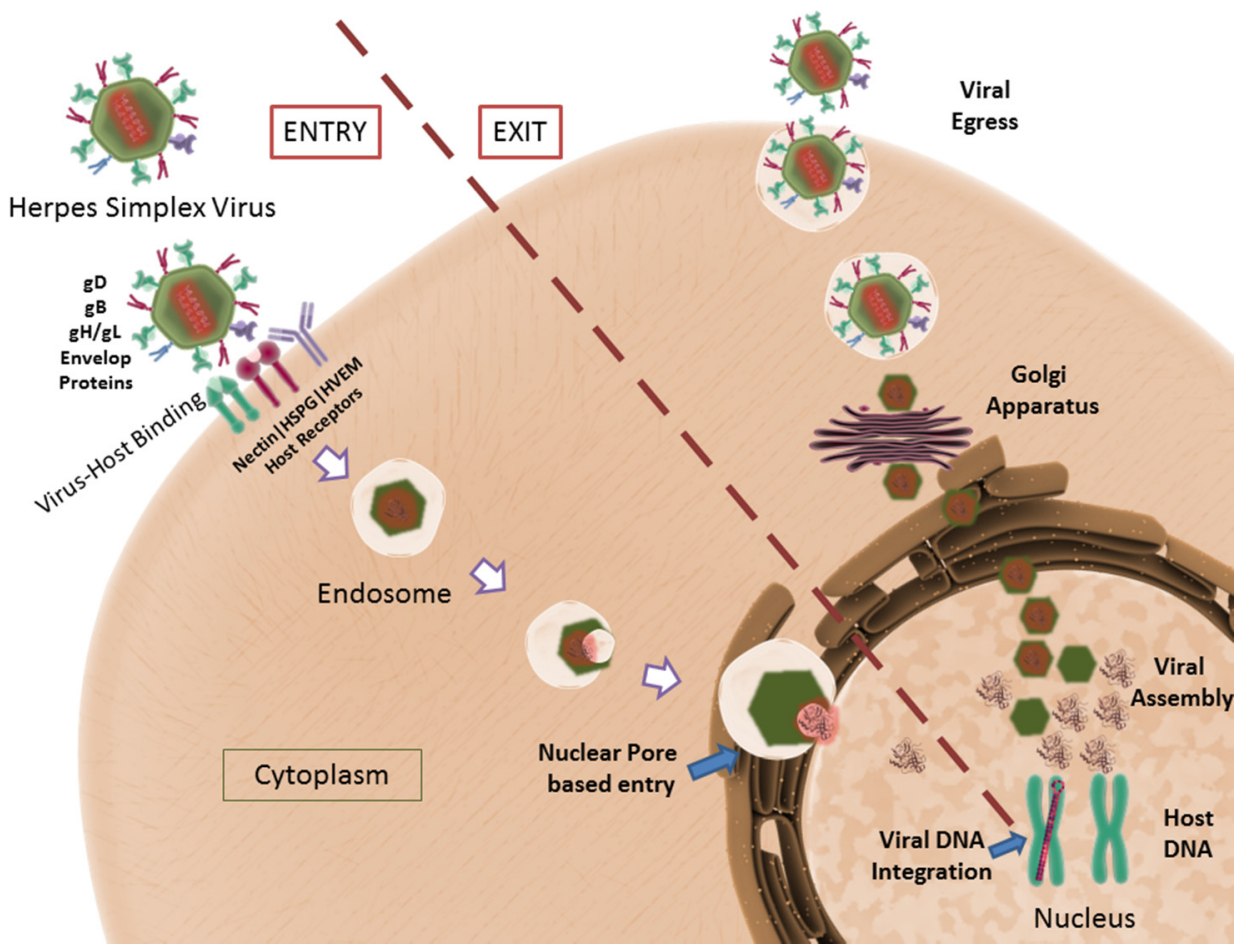

Figure 8. HSV life cycle depicted: The viral proteins $\mathrm{gD}, \mathrm{gB}, \mathrm{gH} / \mathrm{gL}$ facilitate virus-host binding. The host receptors, Nectin, HVEM and HSPG have been shown to assist viral entry. The transcription and translation of viral genes are followed by viral egress. CC BY 4.0 license.

Viral $\mathrm{gB}$ and $\mathrm{gC}$ surface glycoproteins interact with Heparan sulfate proteoglycans (HSPGs) to facilitate the viral attachment to the host cell membrane [155]. Using these proteins, the virus has been shown to surf along the large surface area of filopodia to 
reach the cellular surface, where the receptors required for virus fusion are present. When in close proximity to the cell surface, viral gD interacts with three distinct host surface receptors for fusion and entry, namely, herpes virus entry protein A (HVEA), 3-O-sulphated heparan sulfate, and nectin [155]. After attachment, viral gD binds to nectin and undergoes a conformational change, to interact with viral $\mathrm{gB}$ and $\mathrm{gH} / \mathrm{gL}$, ultimately leading to the fusion of the viral envelope to the host cell membrane. Upon fusion, the viral capsid and the tegument proteins are released into the host's cytoplasm [156].

The viral capsid follows a trans-microtubule network to reach the nuclear pore, where the viral DNA is injected into the nucleus [157]. Simultaneously, tegument proteins enter the cytoplasm of the host to prepare for viral transcription and protein stabilization. Once inside the nucleus, the viral DNA can either initiate a lytic or latent infection cycle. In lytic infections, viral DNA is replicated for further processing, while in latent infections, the DNA is integrated into the host cell genome [158]. Upon initiation of the lytic cycle, immediate early (IE) genes (ICP0, ICP4, ICP22, ICP27, and ICP47) are expressed with the help of VP16 [159]. The ICP4 and ICP27 gene products initiate the expression of early (E) genes that help to regulate the replication/production of viral DNA. To conclude the cycle, late (L) genes are expressed that primarily code for the structural proteins required for viral assembly [160]. However, in the case of latent infection, only latency-associated transcripts (LAT) are transcribed, the function of which is still under investigation [161,162].

Closely regulated expression and transcription of all genes result in the replication and assembly of the viral proteins and genome to form virus particles. A significant contribution in HSV studies was conducted by our group, showing that heparan sulfate, required for the attachment/fusion of the virus to the host cell, is also responsible and implicated in holding newly budded virus particles to the host cell membrane. Heparanase, a host enzyme, is required and upregulated in infected cells, which cleave surface heparan sulfate, aiding viral egress from the cells [163].

\subsection{Aptamers for $H S V$}

There are two interesting studies that have been published in the field of aptamers treating HSV infections. While one study considered aptamers for HSV-1, the other study explored aptamers targeting HSV-2. Both the reports used RNA aptamers in their studies.

Potent aptamers with an IC50 range of 20-50 nM were reported to block infection pathways that were dependent on both major entry receptors, Nectin1 and HVEM of HSV-2, by Moore et al. in 2011 [164]. The study showed the use of a robotic SELEX process to screen for aptamers against the gD protein of HSV-2. The screened aptamers were able to bind to their target with the same binding affinity as a gD antibody. Chinese hamster ovary (CHO) and Vero cell lines were infected with HSV-2 in both the presence and absence of the aptamers and showed a significant reduction in viral replication in the case of aptamer treatment.

In a similar study, Gopinath et al. developed RNA aptamers against the gD of HSV-1 in 2012 [165]. The initial 113-nucleotide RNA was sequentially reduced to 45 nucleotides while keeping its $\mathrm{K}_{\mathrm{d}}$ value approximately constant. The final aptamer had a $\mathrm{K}_{\mathrm{d}}$ value of $40 \mathrm{nM}$, with an IC50 value of $0.8 \mu \mathrm{M}$. This was done by closely monitoring the structural changes that occurred with the removal of non-essential domains from the aptamer.

Our group has reported the use of a DNA aptamer for the treatment of an HSV-1 infection in the eye [166]. The aptamer used the same sequence of the RNA aptamer that Gopinath et al. used to detect the HSV-1 gD, but in its DNA form. The aptamer has a $\mathrm{K}_{\mathrm{d}}$ of $50 \mathrm{nM}$ with an IC50 of $2 \mu \mathrm{M}$ when used in PBS solution. This is the first and only DNA aptamer that has been studied in detail with respect to its therapeutic efficacy, both ex vivo and in vivo. This body of work has the potential to change the current landscape of perspectives on topical antivirals in treating HSV-1 keratitis. Topical antivirals have lower systemic toxicity-based side effects, so using anti-inflammatory and biocompatible drugs such as DNA aptamers can improve a disease prognosis significantly when it comes to HSV-1 keratitis. 
A list of aptamers that have been used for the treatment and diagnosis of other viruses, such as apple stem pitting virus, coronavirus, norovirus, etc., have been tabulated in Table A4 [167-205].

\section{Discussion}

\subsection{Role of Modern Technologies in Developing Aptamers}

As aptamers are characteristically short nucleic acid sequences, any development in the field of nucleic acid research directly influences them. In this regard, the advent of newer and more sophisticated DNA sequencing systems has greatly helped the production of aptamers itself. The SELEX process heavily relies on understanding the repeatability of an oligonucleotide sequence in successive runs. With every successive round of selection, the aptamers that are bound to the target molecule are produced in higher quantities. Prior to 2011, the selected aptamer sequences would then be cloned into bacteria, and the colonies with the highest repeatability would be taken for further consideration. With the advent of next-generation sequencing techniques, a lot of these processes require no cloning or post-selection processing. This has hugely affected aptamer development globally in the past decade. In the last five years, the price for evaluating the sequence of a human-sized genome has fallen further to half its price, resulting in more researchers opting for this technique over older ones. Additionally, the production/commercialization of instruments that have next-gen sequencing capabilities have given researchers access to new tools that they did not have a decade ago [206].

As SELEX comprises a repeated selection process spanning anywhere between 10 and 20 cycles, robotic protocols with minimal human intervention have facilitated an error-free, simple and extremely efficient evolution of aptamers [207]. Combined with next-gen sequencing systems, these robotic protocols have reduced the SELEX timeline (including post-selection modification) from 3 to 6 months to just 6-8 weeks [208]. The list of companies providing various services is reported in Table A5.

The advent of these technological advances, along with growth in global connectivity and sharing, has given rise to companies that commercially produce the aptamers of your choice, based on a given target. SELEX commercialization, combined with academic proficiency, has given rise to numerous commercially available aptamers for a plethora of targets. All these aptamers have been target-tested and include several readily available modifications (such as $3^{\prime}$-his tag, Poly A, Poly T; 5'-GFP, $\mathrm{NH}, \mathrm{CH}_{3} \mathrm{COO}$ ) that can easily be procured by researchers or users and are readily available. This has broadened the scope for aptamers, as researchers with no prior experience in using aptamers now have access to purchase and experiment with them in developing sensors and diagnostic assays for metabolites and infectious diseases.

The process used by Lange et al. in 2012 [26], and previously described in this article, generates an innate host immunity by helping the host cell to produce its own aptamers. This model of treatment would remove the need for an external supply of aptamers and equip the cell with innate immunity in the presence of an infectious agent. Following these kinds of scientific breakthroughs in the treatment of other viral diseases like $\mathrm{HBV}, \mathrm{HCV}$ and HSV is an exciting future prospect for the research community.

\subsection{Role of Computational Approaches in Developing Aptamers}

In addition to traditional SELEX methods, a new wave of computational approaches has taken over in the discovery of high-affinity aptamers that can bind to targets of interest with high specificity. This topic has been extensively covered in review articles by Mohamad Zulkeflee et al. [209] and Chushak and Stone [210]. The groups have exhaustively reviewed the recent advances and applications of computational approaches in aptamer development. Their articles discuss pilot research focused on predicting total aptamer length and a 3D RNA aptamer structure that binds to targets of interest alongside a combination of microarray technologies, computational docking and sequence fitness modeling 
algorithms. Other studies have applied molecular dynamics simulations to predict whether suitable aptamers bind to proteins, peptides, small molecules, and viral antigens.

Using an extensive 3-step process, a high-affinity aptamer prediction can be made. The first step involves the selection of RNA sequences based on their secondary structure, the second step involves the generation of $3 \mathrm{D}$ structures, and the third step involves screening the library of RNA molecules with targets of interest using molecular docking and molecular dynamic simulation programs. While all these techniques are resourceintensive, once generated, they can be used repeatedly and with high accuracy.

\subsection{Aptamers against the SARS-CoV-2 Pandemic}

In light of COVID-19 and the global pandemic caused by the SARS-CoV-2 virus, now, more than ever, aptamer technology can direct and provide a variety of therapeutic and treatment options, especially in those cases of patients with immunocompromised or burdened systems. As of July 2021, a new study has been listed for clinical trials sponsored by Achiko AG, in collaboration with Udayana University Hospital, Indonesia for a saliva-based COVID-19 DNA aptamer test. This trial is significant as, prior to this period, aptamers for antiviral use had no clinical trials listed or published [211].

The study is recruiting participants for a non-randomized trial to explore diagnostic tools outside of the widely used RT-PCR method, which relies heavily on an advanced infrastructure. The proposed DNA aptamer-based test can potentially be rapid to read/diagnose and work in areas with limited infrastructure, without invasive procedures for the collection of samples (saliva examination only). The device used in the study is Aptamex, a product of Achiko's DNA aptamer platform technology - a gold nanoparticlebased test that targets the S1 spike protein on the surface of SARS-CoV-2 and is reported to take approximately $15 \mathrm{~min}$ to use [211].

Multiple studies in the recent past have been conducted in an effort to develop diagnostic systems for the detection of SARS-CoV-2. A handful of studies also show the therapeutic benefit of using aptamers against SARS-CoV-2 and COVID-19. Yang et al. [212] have shown that their aptamer targets the receptor-binding domain of the SARS-CoV2 spike protein sub-unit 1 resulting in the neutralization of the virus. They reported six novel DNA aptamers, screened via the capillary electrophoresis (CE)-based SELEX method, designed to specifically recognize SARS-CoV-2 in human serum samples, in addition to potently inhibiting SARS-CoV-2 infection by blocking the receptor-binding domain (RBD). Conversely, Schmitz et al. [213] showed that their DNA aptamer inhibited the infection of a SARS-CoV-2 pseudovirus through a mechanism independent of the spike RBD. Their study used an automated selection process to identify an aptamer that specifically interacts with spike protein without binding to RBD.

Pramanik et al. [214] developed a theranostic system that can both detect and inactivate SARS-CoV-2. They used a gold nanostar conjugated mechanism that could rapidly detect SARS-CoV-2 antigens in $10 \mathrm{~min}$ through a Rhodamine 6G (Rh-6G) dye-quenching mechanism, reaching a detection limit of $130 \mathrm{fg} / \mathrm{mL}$ or approximately $\sim 8$ viral particles per $\mathrm{mL}$. They also demonstrated that their DNA aptamer-gold nanostar conjugate can stop virus infection by blocking the ACE2 receptor-binding capability while destroying the lipid membrane of the virus. Interestingly, Ando et al. [215] propose the use of an IL-6/IL-6 receptor interaction inhibitor as a possible therapeutic against COVID-19. The IL-6 binding to the IL-6R sub-unit has been implicated in cytokine storm occurrence in the COVID-19 pathology. Their SELEX process to screen for the generation of an RNA aptamer against this interaction not only bound to IL-6R with a dissociation constant of $200 \mathrm{nM}$ but also inhibited the interaction of IL-6R with IL-6. This could be an alternative route to treat the disease, rather than targeting the virus itself.

\section{Conclusions and Future Directions}

The detection and treatment of viral infections using antibodies and conventional drugs have seen success in the past. As described in this review, aptamers unequivocally 
provide similar if not better diagnostic and therapeutic efficiencies, with lower production costs when compared to their predecessors, and without running into issues like microorganism resistance. This can be attributed to their simple structural features, nonimmunogenicity, biocompatibility, non-toxicity, and ease of production. However, their selection using the SELEX process remains a major hurdle in developing aptamers for viral infections.

The aptamer industry has come a long way since its humble inception in the early 1990s. Today, we have access to numerous aptamers that are not only competitive with the antibody industry but are also paving the way for novel, complication-free modes of treatment. However, the research on aptamers and their prospects has only begun and will need far greater amounts of funding and focused research to unleash their true potential and results.

From the previous sections, it is evident that some infectious agents, such as HIV and $\mathrm{HCV}$, have received massive attention in the past decade, while others such as HBV and HSV have received less or no attention at all. While all these pathogens have been well studied, and their structures and lifecycles have been clearly charted out, there is disproportionate funding/research being provided/conducted for tackling these issues. Although this depends on the research focus of the funding agencies that support a research group, new reforms in research to eliminate non-lethal diseases also need to be created. In addition, further research has to be focused on translational research in the field of antiviral aptamers, for studies to reach clinical trials. This will shift the current research and healthcare industry paradigm toward using more adaptive, cost-effective and targeted technologies.

With the advent of new companies that commercialize the aptamer generation process, there is space for fruitful collaborations between industry and academia to develop novel aptamers for the diagnosis and therapy of various diseases, such as HSV, that continue to remain evasive while carrying out tremendous damage to public health.

Author Contributions: Conceptualization, T.Y. and D.S.; resources, D.S.; writing-original draft preparation, T.Y.; writing-review and editing, T.Y., I.V.; visualization, T.Y.; supervision, D.S.; project administration, D.S.; funding acquisition, D.S. All authors have read and agreed to the published version of the manuscript.

Funding: This research was funded by the National Institute of Health, National Eye Institute, grant number EY024710.

Institutional Review Board Statement: Not applicable.

Informed Consent Statement: Not applicable.

Data Availability Statement: Not applicable.

Acknowledgments: The authors would like to acknowledge the help provided by Patrick Przybylo in reviewing and adding requisite references to the manuscript.

Conflicts of Interest: The authors declare no conflict of interest. The funders had no role in the design of the study; in the collection, analyses, or interpretation of data; in the writing of the manuscript, or in the decision to publish the results.

\section{Appendix A}

Table A1. List of aptamers and their properties for treatment and detection of HIV.

\begin{tabular}{ccccccc}
\hline Reference & $\begin{array}{c}\text { Detection/ } \\
\text { Therapy }\end{array}$ & $\begin{array}{c}\text { Mode of } \\
\text { Detection/Therapy }\end{array}$ & $\begin{array}{c}\text { Detection Range or } \\
\text { Binding Affinity }\end{array}$ & Target & $\begin{array}{c}\text { RNA/ } \\
\text { DNA }\end{array}$ & Size \\
\hline$[47]$ & Detection & - & low pM & HIV-1 RT & RNA & $20+57 \mathrm{nt}$ \\
\hline$[46]$ & Detection & - & 30 aM detection & - & - & - \\
\hline$[45]$ & Detection & $\begin{array}{c}\text { Atomic Force } \\
\text { Microscopy }\end{array}$ & $0.8 \mathrm{nM}$ to $8 \mathrm{pM}$ & gp120 & DNA & 2015 \\
\hline
\end{tabular}


Table A1. Cont.

\begin{tabular}{|c|c|c|c|c|c|c|c|}
\hline Reference & $\begin{array}{l}\text { Detection/ } \\
\text { Therapy }\end{array}$ & $\begin{array}{c}\text { Mode of } \\
\text { Detection/Therapy }\end{array}$ & $\begin{array}{l}\text { Detection Range or } \\
\text { Binding Affinity }\end{array}$ & Target & $\begin{array}{l}\text { RNA/ } \\
\text { DNA }\end{array}$ & Size & Year \\
\hline [43] & Detection & rGO Flourescence & - & interferon- $\gamma$ & DNA & - & 2014 \\
\hline [44] & Detection & $\mathrm{K}_{\mathrm{d}}=2-4 \mathrm{nM}$ & $28 \mathrm{nM}$ & $\begin{array}{c}\text { nucleocapsid } \\
\text { protein } 7 \text { (NCp7) }\end{array}$ & RNA & 20 nt SL3 Aptamer & 2013 \\
\hline [41] & Detection & $\begin{array}{l}\text { Diamond-FET-based- } \\
\text { sensing }\end{array}$ & $1 \mathrm{nM}$ & HIV-1 Tat protein & RNA & $\begin{array}{l}19 \text { nt Sigma Aldrich, St. } \\
\text { Louis, MO 68178, USA }\end{array}$ & 2013 \\
\hline [42] & Detection & Imaging & $\mathrm{K}_{\mathrm{d}} 2.5 \times 10^{-8} \mathrm{M}$ & HIV-1 RT & DNA & $\begin{array}{c}93 \text { nt G-Quadruplex } \\
\text { Sangon Biotech, } 698 \\
\text { Xiangyu Road, Songjiang } \\
\text { District, Shanghai Zip } \\
\text { Code: } 201611 \text { - }\end{array}$ & 2011 \\
\hline [40] & Detection & $\begin{array}{l}\text { Diamond-FET-based } \\
\text { sensing }\end{array}$ & $1 \mathrm{pM}$ to $1 \mu \mathrm{g} / \mathrm{ml}$ & HIV 1 tat peptide & RNA & $\begin{array}{c}36 \text { nt Sigma Genesis } \\
\text { company, St. Louis, MO } \\
68178, \text { USA }\end{array}$ & 2011 \\
\hline [39] & $\begin{array}{l}\text { Detection } \\
\text { and } \\
\text { Therapy }\end{array}$ & $\begin{array}{c}\text { Transfection-based } \\
\text { assay }\end{array}$ & $\begin{array}{l}\text { Prediction of best } \\
\text { inhibitors }\end{array}$ & HIV RT & RNA & - & 2014 \\
\hline [48] & Detection & MST Measurement & $10 \mu \mathrm{M}$ & HIV-1 integrase & DNA & & 2016 \\
\hline [49] & Detection & QIAamp kit & $29 \mathrm{nM}$ & gp120 & RNA & $29 \mathrm{nt}$ & 2016 \\
\hline [50] & Detection & qPCR & & gag protein & RNA & $80 \mathrm{nt}$ & 2017 \\
\hline [50] & Detection & ELISA & High affinity & RT & RNA & & 2017 \\
\hline [51] & Detection & SELEX & High affinity & RT & DNA & $31 \mathrm{nt}$ & 2017 \\
\hline [52] & Detection & $\begin{array}{c}\text { G- } \\
\text { quadruplex/QTAp }\end{array}$ & High affinity & Tat protein & RNA & $14 \mathrm{nt}$ & 2017 \\
\hline [53] & Therapy & AS1411 & Clinical Trials & Nucleolin & RNA & - & 2015 \\
\hline [54] & Therapy & Anti-TNPO3 siRNA & - & anti-CCR5 receptor & RNA & - & 2015 \\
\hline [17] & Therapy & Live cell SELEX & - & anti-CCR5 receptor & RNA & - & 2015 \\
\hline [22] & Therapy & Protease inhibition & - & aspartyl protease & RNA & - & 2015 \\
\hline [22] & Therapy & Entry Inhibitors & - & gp120, gp41 & RNA & - & 2015 \\
\hline [19] & Therapy & Chimeras & - & gp120 or CD4 & RNA & - & 2015 \\
\hline [21] & Therapy & $\begin{array}{l}\text { Stops HIV-C from } \\
\text { causing } \\
\text { cardiomyopathy }\end{array}$ & - & UCLA1 & RNA & Modified UCLA & 2014 \\
\hline [16] & Therapy & $\begin{array}{l}\text { Aptamer shortening } \\
\text { up to their minimal } \\
\text { active domain }\end{array}$ & $\begin{array}{l}\text { 85\% inhibition of } \\
\text { HIV }\end{array}$ & $\begin{array}{l}5^{\prime} \text {-untranslated } \\
\text { region of HIV-1 } \\
\text { genome }\end{array}$ & RNA & $16 \mathrm{nt}$ & 2014 \\
\hline [20] & Therapy & $\mathrm{EC}_{50} 4.9-10 \mu \mathrm{M}$ & - & gp120 & DNA & $\begin{array}{l}\text { G-quadruplex-forming } \\
\text { d(TG3AG) }\end{array}$ & 2014 \\
\hline [18] & Therapy & $\begin{array}{l}\text { RNA screening } \\
\text { system }\end{array}$ & - & HIV RT & RNA & - & 2014 \\
\hline [58] & Therapy & $70 \%$ inhibition & $\mathrm{K}_{\mathrm{d}}=1.59 \mathrm{nM}$ & CD40 & DNA & $45 \mathrm{nt}$ & 2014 \\
\hline [34] & Therapy & - & - & $\begin{array}{l}\text { gp120, gp41 and } \\
\text { HSA }\end{array}$ & DNA & $\begin{array}{l}\text { G-quadruplex-forming } \\
\text { d(TG3AG) }\end{array}$ & 2014 \\
\hline [59] & Therapy & $\begin{array}{l}\text { Functionalized Gold } \\
\text { nano }\end{array}$ & $\begin{array}{l}40.2 \% \text { decreased } \\
\text { infectivity }\end{array}$ & HIV-1 RT & RNA & $\begin{array}{c}\text { IDT company, } 1710 \\
\text { Commercial Park, } \\
\text { Coralville, Iowa 52241, } \\
\text { USA }\end{array}$ & 2013 \\
\hline [60] & Therapy & $\begin{array}{l}\text { Hydrophobic } \\
\text { aptamer }\end{array}$ & - & $\begin{array}{l}\text { gp41 N-terminal } \\
\text { heptad repeat } \\
\text { (NHR) }\end{array}$ & DNA & DNA Duplex & 2013 \\
\hline [19] & Therapy & $\begin{array}{l}\text { Reduced topical } \\
\text { dosage compard to } \\
\text { earlier studies }\end{array}$ & - & $\mathrm{CD} 4$ & RNA & $40 \mathrm{nt}$ & 2013 \\
\hline [38] & Therapy & - & $\mathrm{IC}_{50} 10 \mathrm{nM}$ & HIV-1 RT & RNA & $31 \mathrm{nt}$ & 2013 \\
\hline [61] & Therapy & Binding Inhibition & - & P24 antigen & RNA & - & 2013 \\
\hline
\end{tabular}


Table A1. Cont.

\begin{tabular}{|c|c|c|c|c|c|c|c|}
\hline Reference & $\begin{array}{l}\text { Detection/ } \\
\text { Therapy }\end{array}$ & $\begin{array}{c}\text { Mode of } \\
\text { Detection/Therapy }\end{array}$ & $\begin{array}{l}\text { Detection Range or } \\
\text { Binding Affinity }\end{array}$ & Target & $\begin{array}{l}\text { RNA/ } \\
\text { DNA }\end{array}$ & Size & Year \\
\hline [62] & Therapy & $\begin{array}{l}\text { Rev Aptamer } \\
\text { improvement }\end{array}$ & - & $\begin{array}{c}\text { arginine-rich motif } \\
\text { (ARM) of HIV Rev } \\
\text { protein }\end{array}$ & RNA & $30 \mathrm{nt}$ & 2013 \\
\hline [37] & Therapy & $\begin{array}{l}\text { High Through-put } \\
\text { sequencing enhances } \\
\text { chances for better } \\
\text { selection }\end{array}$ & - & HIV-1 RT & RNA & $70 \mathrm{nt}$ & 2013 \\
\hline$[63]$ & Therapy & $\mathrm{IC}_{50}$ value of $0.5 \mathrm{mM}$ & $\mathrm{K}_{\mathrm{d}}=29-381 \mathrm{nM}$ & interleukin-6 & DNA & $60 \mathrm{nt}$ & 2013 \\
\hline [16] & Therapy & $\begin{array}{l}\text { Chemical } \\
\text { Modification to } \\
\text { attach siRNA }\end{array}$ & - & gp120 & RNA & - & 2013 \\
\hline$[36]$ & Therapy & $\begin{array}{l}\text { Intracellular } \\
\text { Aptamer }\end{array}$ & $\begin{array}{c}\text { 5-10 fold } \\
\text { suppression }\end{array}$ & HIV RT & RNA & - & 2012 \\
\hline$[35]$ & Therapy & $\begin{array}{c}\text { Structural } \\
\text { Investigation of } \\
\text { G-Quadruplexes }\end{array}$ & - & - & DNA & $\begin{array}{c}\text { G-quadruplex-forming } \\
\text { d(TG3AG) }\end{array}$ & 2012 \\
\hline$[64]$ & Therapy & $\begin{array}{l}\text { siRNA attached to } \\
\text { Aptamer }\end{array}$ & - & CD4 & DNA & $\begin{array}{l}\text { Made from RNA } \\
\text { Aptamer } 39 \mathrm{nt}\end{array}$ & 2012 \\
\hline [65] & Therapy & - & - & CCR5 & DNA & $23 \mathrm{nt}$ & 2012 \\
\hline [66] & Therapy & $\begin{array}{l}\text { Blocking HIV } \\
\text { translation }\end{array}$ & $\begin{array}{c}\mathrm{K}_{\mathrm{d}}=1.28 \pm 1.27 \\
\mathrm{nmol} / \mathrm{l}\end{array}$ & human cyclin T1 & RNA & $40 \mathrm{nt}$ & 2012 \\
\hline [67] & Therapy & - & $\mathrm{K}_{\mathrm{d}}=82 \pm 7 \mathrm{nM}$ & HIV RT & DNA & G-Quadruplex & 2012 \\
\hline [20] & Therapy & $\mathrm{IC}_{50} 0.8 \pm 0.9 \mathrm{nM}$ & $\mathrm{K}_{\mathrm{d}}=0.15 \mathrm{nM}$ & gp120 & RNA & 54 nt UCLA-1 first report & 2012 \\
\hline$[68]$ & Therapy & $\begin{array}{l}\text { Stops Early } \\
\text { intracellular events }\end{array}$ & - & Thrombin, RT & DNA & 3 DNA G-Quadruplexes & 2011 \\
\hline [69] & Therapy & $\begin{array}{c}\text { Targeted Delievery of } \\
\text { pRNA }\end{array}$ & $\mathrm{K}_{\mathrm{d}}=47.91 \mathrm{nM}$ & gp120 & RNA & $81 \mathrm{nt}$ Aptamer & 2011 \\
\hline [18] & Therapy & $\begin{array}{l}\text { RNA aptamer with } \\
\text { siRNA Chimera }\end{array}$ & - & $\mathrm{CD} 4$ & RNA & 86 nt-Aptamer A1 & 2011 \\
\hline$[70]$ & Therapy & $\begin{array}{l}\text { Aptamer-siRNA } \\
\text { Chimera }\end{array}$ & $\mathrm{K}_{\mathrm{d}}=47.91 \mathrm{nM}$ & gp120 & RNA & 86 nt-Aptamer A1 & 2011 \\
\hline$[71]$ & Therapy & $\begin{array}{l}\text { HSCs are engineered } \\
\text { to express anti-HIV } \\
\text { molecules }\end{array}$ & $\mathrm{K}_{\mathrm{d}}=80$ to $200 \mathrm{nM}$ & gag polyprotein & RNA & $100 \mathrm{nt}$ & 2011 \\
\hline
\end{tabular}

Table A2. List of aptamers and their properties for treatment and detection of Hepatitis B, C and D virus subtypes.

\begin{tabular}{|c|c|c|c|c|c|c|c|}
\hline Reference & $\begin{array}{l}\text { Detection/ } \\
\text { Therapy }\end{array}$ & $\begin{array}{c}\text { Mode of } \\
\text { Detection/Therapy }\end{array}$ & $\begin{array}{l}\text { Detection Range or } \\
\text { Binding Affinity }\end{array}$ & Target & $\begin{array}{l}\text { RNA/ } \\
\text { DNA }\end{array}$ & Size & Year \\
\hline [90] & $\begin{array}{l}\text { Detection } \\
\text { - HBV }\end{array}$ & Chemiluminiscence & $0.5 \mathrm{ng} / \mathrm{L}$ & Surface Antigen & DNA & - & 2015 \\
\hline [89] & $\begin{array}{l}\text { Detection- } \\
\text { HBV }\end{array}$ & $\begin{array}{c}\text { one-step competitive } \\
\text { binding assay }\end{array}$ & $1.25 \mathrm{mIU}$ mL-1 & $\begin{array}{c}\text { surface antigen of } \\
\text { the hepatitis B } \\
\text { virus }\end{array}$ & RNA & $99 \mathrm{nt}$ & 2014 \\
\hline$[94]$ & $\begin{array}{l}\text { Detection- } \\
\text { HCV }\end{array}$ & ELISA & - & $\begin{array}{l}\text { glycoproteins, E1 } \\
\text { and E2 }\end{array}$ & RNA & & 2015 \\
\hline$[92,93]$ & $\begin{array}{c}\text { Detection- } \\
\text { HCV }\end{array}$ & ELASA-First time & $0.8-4 \mathrm{nM}$ & HCV E2 & DNA & $40 \mathrm{nt}$ & 2013 \\
\hline [92] & $\begin{array}{l}\text { Detection } \\
\text {-HCV }\end{array}$ & lateral flow strip & $10 \mathrm{pg} / \mathrm{mL}$ & $\mathrm{HCV}$ core antigen & DNA & - & 2013 \\
\hline [95] & $\begin{array}{l}\text { Detection- } \\
\text { HCV }\end{array}$ & $\begin{array}{l}\text { Malachite green } \\
\text { flourescence }\end{array}$ & $250 \mathrm{nM}$ & $\begin{array}{c}\text { hepatitis } C \text { helicase } \\
\text { and replicase }\end{array}$ & RNA & - & 2013 \\
\hline [91] & $\begin{array}{l}\text { Detection- } \\
\text { HCV }\end{array}$ & Octet interferometer & $700 \mathrm{pg} / \mathrm{ml}$ & NS5B viral protein & RNA & $\begin{array}{l}21 \text { nt NS5B RNA } \\
\text { BIONEER }\end{array}$ & 2011 \\
\hline [188] & $\begin{array}{l}\text { Detection- } \\
\text { HBV }\end{array}$ & SELEX & $4 \mu \mathrm{M}$ & HbeAg & DNA & $40 \mathrm{nt}$ & 2016 \\
\hline
\end{tabular}


Table A2. Cont.

\begin{tabular}{|c|c|c|c|c|c|c|c|}
\hline Reference & $\begin{array}{l}\text { Detection/ } \\
\text { Therapy }\end{array}$ & $\begin{array}{c}\text { Mode of } \\
\text { Detection/Therapy }\end{array}$ & $\begin{array}{l}\text { Detection Range or } \\
\text { Binding Affinity }\end{array}$ & Target & $\begin{array}{l}\text { RNA/ } \\
\text { DNA }\end{array}$ & Size & Year \\
\hline [206] & $\begin{array}{l}\text { Detection- } \\
\text { HBV }\end{array}$ & $\begin{array}{c}\mathrm{AgNC} \text { and MoS2 } \\
\text { nanosheets }\end{array}$ & $10.7 \mathrm{nM}$ & pLDH & DNA & $29 \mathrm{nt}$ & 2017 \\
\hline [195] & $\begin{array}{l}\text { Detection- } \\
\text { HCV }\end{array}$ & nanoaptasensor & $10 \mu \mathrm{m}$ & HCVcoreAg & DNA & & 2017 \\
\hline [214] & $\begin{array}{l}\text { Detection- } \\
\text { HCV }\end{array}$ & ELISA & $10^{-10} \mathrm{M}$ & HCVcoreAg & DNA & $85 \mathrm{nt}$ & 2018 \\
\hline [211] & $\begin{array}{l}\text { Detection- } \\
\text { HCV }\end{array}$ & & High affinity & Ribozyme & RNA & & 2017 \\
\hline [204] & $\begin{array}{l}\text { Detection- } \\
\text { HCV }\end{array}$ & ELISA & & HCV polyprotein & DNA & $80 \mathrm{nt}$ & 2017 \\
\hline$[78,79]$ & $\begin{array}{l}\text { Therapy- } \\
\text { HBV }\end{array}$ & inhibition & $180 \pm 82 \mathrm{nM}$ & Surface protein L & DNA & - & 2015 \\
\hline [78] & $\begin{array}{l}\text { Therapy- } \\
\text { HBV }\end{array}$ & $\begin{array}{l}\text { inhibit the assembly } \\
\text { of the nucleocapsid }\end{array}$ & - & $\begin{array}{c}\text { core protein of } \\
\text { HBV }\end{array}$ & DNA & $\begin{array}{c}\text { Sangon Biotech, } 698 \\
\text { Xiangyu Road, Songjiang } \\
\text { District, Shanghai Zip } \\
\text { Code: } 201611\end{array}$ & 2014 \\
\hline [76] & $\begin{array}{l}\text { Therapy- } \\
\text { HBV }\end{array}$ & Inhibition & - & HBV P protein & RNA & $29 \mathrm{nt}$ & 2011 \\
\hline [96] & $\begin{array}{l}\text { Therapy- } \\
\text { HDV }\end{array}$ & $\begin{array}{l}\text { Detection of HDV } \\
\text { Riboswitch }\end{array}$ & ON/OFF 4.7 & HDV Ribozyme & RNA & $8 \mathrm{nt}$ & 2013 \\
\hline$[85,88]$ & $\begin{array}{l}\text { Therapy- } \\
\text { HCV }\end{array}$ & $\begin{array}{c}\text { Chol attached } \\
\text { Aptamer }\end{array}$ & - & $\begin{array}{l}\text { nonstructural } \\
\text { protein } 5 B\end{array}$ & RNA & $29 \mathrm{nt}$ & 2015 \\
\hline$[88,97]$ & $\begin{array}{l}\text { Therapy- } \\
\text { HCV }\end{array}$ & Magnetic Separation & - & E1E2 glycoprotein & RNA & - & 2015 \\
\hline [97] & $\begin{array}{l}\text { Therapy- } \\
\text { HCV }\end{array}$ & $\begin{array}{l}\text { inhibited HCV RNA } \\
\text { replication }\end{array}$ & - & NS2 protein & DNA & $40 \mathrm{nt}$ & 2014 \\
\hline [98] & $\begin{array}{l}\text { Therapy- } \\
\text { HCV }\end{array}$ & Inhibition & - & core protein & DNA & $40 \mathrm{nt}$ & 2014 \\
\hline [99] & $\begin{array}{l}\text { Therapy- } \\
\text { HCV }\end{array}$ & Inhibition & - & NS5A & DNA & $40 \mathrm{nt}$ & 2014 \\
\hline [87] & $\begin{array}{l}\text { Therapy- } \\
\text { HCV }\end{array}$ & $\begin{array}{l}\text { blockage of virus } \\
\text { binding to cells }\end{array}$ & $\mathrm{EC}_{50} 62.37 \mathrm{nM}$ & $\begin{array}{l}\text { envelope protein } \\
\text { (E1E2) }\end{array}$ & DNA & $40 \mathrm{nt}$ & 2013 \\
\hline [84] & $\begin{array}{c}\text { Therapy- } \\
\text { HCV }\end{array}$ & $\begin{array}{l}\text { competitive } \\
\text { sequestration of the } \\
\text { target protein }\end{array}$ & $1-3 \mathrm{nM}$ & $\begin{array}{l}\text { HCV NS5B RNA } \\
\text { replicas }\end{array}$ & RNA & $29 \mathrm{nt}$ & 2013 \\
\hline$[80,82]$ & $\begin{array}{l}\text { Therapy- } \\
\text { HCV }\end{array}$ & $\begin{array}{l}\text { interference of } \mathrm{HCV} \\
\text { replication }\end{array}$ & $0.4-0.5 \mu \mathrm{M}$ & $\begin{array}{l}\text { CRE-5BSL3.2 } \\
\text { domain }\end{array}$ & RNA & $30 \mathrm{nt}$ & 2013 \\
\hline [80] & $\begin{array}{l}\text { Therapy- } \\
\text { HCV }\end{array}$ & - & $\begin{array}{l}80 \% \text { inhibition of } \\
\text { Viral RNA }\end{array}$ & $\begin{array}{l}\text { HCV-CRE194 RNA } \\
\text { fragments }\end{array}$ & RNA & $30 \mathrm{nt}$ & 2012 \\
\hline
\end{tabular}

Table A3. List of aptamers and their properties for treatment and detection of influenza virus subtypes.

\begin{tabular}{|c|c|c|c|c|c|c|c|c|}
\hline Reference & $\begin{array}{l}\text { Influenza } \\
\text { Type }\end{array}$ & $\begin{array}{l}\text { Detection/ } \\
\text { Therapy }\end{array}$ & $\begin{array}{l}\text { Mode of Detec- } \\
\text { tion/Therapy }\end{array}$ & $\begin{array}{l}\text { Detection Range } \\
\text { or Binding } \\
\text { Affinity }\end{array}$ & Target & $\begin{array}{l}\text { RNA/ } \\
\text { DNA }\end{array}$ & Size & Year \\
\hline [136] & & Detection & - & $1 \mu \mathrm{g} / \mathrm{mL}$ & $\begin{array}{l}\text { viral nucleoprotein } \\
\text { and vasopressin }\end{array}$ & DNA & $\begin{array}{l}\text { Nucleoprotein - } 63 \text { nt } \\
\text { AptaRes Ag \& } \\
\text { Vasopressin-54 nt } \\
\text { IDT company, } 1710 \\
\text { Commercial Park, } \\
\text { Coralville, Iowa } \\
\text { 52241, USA }\end{array}$ & 2012 \\
\hline [137] & $\begin{array}{l}\text { influenza } \\
\text { A/H1N1 }\end{array}$ & Detection & $\begin{array}{l}\text { Microfluidic } \\
\text { SELEX }\end{array}$ & $\begin{array}{c}\mathrm{K}_{\mathrm{d}}=55.14 \pm \\
22.40 \mathrm{nM}\end{array}$ & Whole Virus & DNA & $40 \mathrm{nt}$ & 2014 \\
\hline
\end{tabular}


Table A3. Cont.

\begin{tabular}{|c|c|c|c|c|c|c|c|c|}
\hline Reference & $\begin{array}{l}\text { Influenza } \\
\text { Type }\end{array}$ & $\begin{array}{l}\text { Detection/ } \\
\text { Therapy }\end{array}$ & $\begin{array}{l}\text { Mode of Detec- } \\
\text { tion/Therapy }\end{array}$ & $\begin{array}{l}\text { Detection Range } \\
\text { or Binding } \\
\text { Affinity }\end{array}$ & Target & $\begin{array}{l}\text { RNA/ } \\
\text { DNA }\end{array}$ & Size & Year \\
\hline [138] & $\begin{array}{l}\text { Both A } \\
\text { and B }\end{array}$ & Detection & $\begin{array}{l}\text { Gold nano } \\
\text { attachment to } \\
\text { virus }\end{array}$ & $\mathrm{K}_{\mathrm{d}}=44 \pm 6 \mathrm{nM}$ & $\begin{array}{l}\text { hemagglutinin } \\
\text { (HA) and } \\
\text { neuraminidase } \\
\text { (NA) }\end{array}$ & RNA & Various sizes & 2014 \\
\hline [119] & H1N1 & Detection & ELISA/SPR & $\mathrm{nM}$ range & $\begin{array}{l}\text { Surface protein } \\
\text { hemagglutinin } \\
\text { HA1 subunit of } \\
\text { subtype H1 }\end{array}$ & DNA & G-quadruplex & 2015 \\
\hline [139] & $\begin{array}{l}\text { H3N2, } \\
\text { H2N2, } \\
\text { H5N1, } \\
\text { H1N1 }\end{array}$ & Detection & $\begin{array}{c}\mathrm{K}_{\mathrm{d}} \text { Tokio } 0.7 \pm 0.2 \\
\text { and Jilin } \\
1.2 \pm 0.2 \mu \mathrm{g} / \mathrm{mL}\end{array}$ & $\begin{array}{l}\text { Tokio virus } \\
8 \mathrm{ng} / \mathrm{mL} \\
\text { Jilin-HA } \\
800 \mathrm{ng} / \mathrm{mL}\end{array}$ & Viral SELEX & RNA & $25 \mathrm{nt}$ & 2013 \\
\hline [133] & H5N1 & Detection & $\begin{array}{l}\text { Sandwich assay } \\
\text { amperometric }\end{array}$ & $100 \mathrm{fM}$ & H5N1 specific & DNA & $72 \mathrm{nt}$ & 2015 \\
\hline [131] & H5N1 & Detection & Impedance & $\begin{array}{c}0.0128 \\
\text { hemagglutinin } \\
\text { units (HAU) }\end{array}$ & H5N1 specific & DNA & - & 2015 \\
\hline [130] & H5N1 & Detection & $\begin{array}{l}\text { Gold Nanogate } \\
\text { enzymatic sensor }\end{array}$ & 2-9 HAU & H5N1 & DNA & - & 2015 \\
\hline [140] & H5N1 & Detection & $\begin{array}{l}\text { metal-enhanced } \\
\text { fluorescence } \\
\text { (MEF) sensing } \\
\text { platform }\end{array}$ & 2 and $3.5 \mathrm{ng} / \mathrm{mL}$ & $\begin{array}{l}\text { recombinant } \\
\text { hemagglutinin } \\
(\mathrm{rHA}) \text { protein }\end{array}$ & DNA & G-quadruplex & 2015 \\
\hline [129] & H5N1 & Detection & $\begin{array}{l}\text { enzymatic } \\
\text { catalysis with } \\
\text { electrochemical } \\
\text { impedance }\end{array}$ & $\begin{array}{c}8 \times 10^{-4} \mathrm{HAU} \text { in } \\
200 \mu \mathrm{L}\end{array}$ & recombinant IGF-I & DNA & 72-nt biotin labelled & 2014 \\
\hline [128] & H5N1 & Detection & $\left(\mathrm{K}_{\mathrm{d}}\right)$ of $4.65 \mathrm{nM}$ & $12.8 \mathrm{HAU}$ & hemagglutinin & DNA & N74 & 2013 \\
\hline [127] & H5N1 & Detection & $\begin{array}{l}\text { QCM based } \\
\text { sensor }\end{array}$ & $\begin{array}{c}0.0128 \text { to } 128 \\
\text { HAU }\end{array}$ & $\begin{array}{l}\text { H5N1 surface } \\
\text { protein }\end{array}$ & DNA & $\begin{array}{c}75 \text { nt IDT Company, } \\
1710 \text { Commercial } \\
\text { Park, Coralville, } \\
\text { Iowa 52241, USA }\end{array}$ & 2013 \\
\hline [126] & H5N1 & Detection & $\begin{array}{l}\text { SPR based } \\
\text { portable sensor }\end{array}$ & $\begin{array}{c}0.128 \text { to } 1.28 \\
\text { HAU }\end{array}$ & $\begin{array}{l}\text { haemagglutinin } \\
\text { (HA }\end{array}$ & DNA & $74 \mathrm{nt}$ & 2012 \\
\hline [132] & $\mathrm{H} 5 \mathrm{~N} 1$ & Detection & Electrochemical & $4.3 \times 10^{-13} \mathrm{M} / \mathrm{L}$ & $\begin{array}{l}\text { AIV H5N1 gene } \\
\text { sequences }\end{array}$ & DNA & $\begin{array}{c}23 \text { nt Takara Biotech, } \\
2560 \text { Orchard } \\
\text { Parkway, San Jose, } \\
\text { CA 95131, USA }\end{array}$ & 2011 \\
\hline [141] & $\begin{array}{l}\text { H5N1, } \\
\text { H1N1, } \\
\text { and } \\
\text { H3N2 }\end{array}$ & Detection & $\begin{array}{c}\text { sandwich } \\
\text { enzyme-linked } \\
\text { aptamer assay }\end{array}$ & $\begin{array}{c}\mathrm{K}_{\mathrm{d}} 1.53 \times 10^{-8} \\
\mathrm{M}\end{array}$ & HA1 protein & DNA & - & 2014 \\
\hline [142] & $\begin{array}{c}\text { Influenza } \\
\mathrm{A}\end{array}$ & Detection & Labelling & Visual & $\begin{array}{l}\text { hemagglutinin } \\
\text { (HA) }\end{array}$ & DNA & $\begin{array}{c}68 \mathrm{nt} \text { Sangon biotech, } \\
698 \text { Xiangyu Road, } \\
\text { Songjiang District, } \\
\text { Shanghai Zip Code: } \\
201611\end{array}$ & 2011 \\
\hline [135] & - & Detection & SERS & $0.1 \mu \mathrm{g} / \mathrm{ml}$ & $\begin{array}{c}\text { Viral } \\
\text { Nucleoprotein }\end{array}$ & DNA & 22 nt AptaRes AG & 2011 \\
\hline [103] & $\begin{array}{c}\text { Influenza } \\
\text { A }\end{array}$ & Detection & $\begin{array}{l}\text { activatable silver } \\
\text { nanoclusters } \\
\text { beacon }\end{array}$ & High affinity & $\begin{array}{l}\text { H1N1/H5N1 } \\
\text { genes }\end{array}$ & DNA & small nt sequence & 2017 \\
\hline [143] & H3N2 & Detection & $\begin{array}{l}\text { Impedimetric } \\
\text { glycan-based } \\
\text { biosensor }\end{array}$ & $5 \mathrm{aM}$ & Glycan & DNA & & 2016 \\
\hline [144] & H5N1 & Detection & $\begin{array}{l}\text { nanowell-based } \\
\text { QCM aptasensor }\end{array}$ & 2-4 HAU $/ 50 \mu \mathrm{L}$ & $\begin{array}{l}\text { hemagglutin } \\
\text { glycoprotein }\end{array}$ & DNA & & 2017 \\
\hline
\end{tabular}


Table A3. Cont.

\begin{tabular}{|c|c|c|c|c|c|c|c|c|}
\hline Reference & $\begin{array}{l}\text { Influenza } \\
\text { Type }\end{array}$ & $\begin{array}{l}\text { Detection/ } \\
\text { Therapy }\end{array}$ & $\begin{array}{l}\text { Mode of Detec- } \\
\text { tion/Therapy }\end{array}$ & $\begin{array}{l}\text { Detection Range } \\
\text { or Binding } \\
\text { Affinity }\end{array}$ & Target & $\begin{array}{l}\text { RNA/ } \\
\text { DNA }\end{array}$ & Size & Year \\
\hline [145] & H9N2 & Detection & RT-I-PCR & $\mathrm{K}_{\mathrm{d}}=40.67 \mathrm{nM}$ & H9 gene & DNA & $26 \mathrm{nt}$ & 2017 \\
\hline [146] & H3N2 & Detection & $\begin{array}{l}\text { Dual Recognition } \\
\text { Element Lateral } \\
\text { Flow Assay }\end{array}$ & $\begin{array}{l}2 \times 10^{-6} \text { virus } \\
\text { particles }\end{array}$ & $\begin{array}{c}\text { A/Panama/2007/99 } \\
\text { (H3N2) }\end{array}$ & RNA & $75 \mathrm{nt}$ & 2014 \\
\hline [122] & H5N2 & Therapy & $70 \%$ cell viability & & hemagglutinin & RNA & $40 \mathrm{nt}$ & 2014 \\
\hline [123] & H5N2 & Therapy & $\begin{array}{l}\text { Selection and } \\
\text { Binding }\end{array}$ & $\begin{array}{c}\text { Significant } \\
\text { inhibition of HA }\end{array}$ & hemagglutinin & RNA & $40 \mathrm{nt}$ & 2011 \\
\hline [125] & H9N2 & Therapy & $\begin{array}{c}\text { capillary } \\
\text { electrophoresis } \\
\text { SELEX }\end{array}$ & & $\begin{array}{l}\text { H9N2 AIV purified } \\
\text { haemagglutinin }\end{array}$ & DNA & - & 2015 \\
\hline [124] & H9N2 & Therapy & 3-fold survival & $\begin{array}{l}\text { Same affinity as } \\
\text { mouse antibody }\end{array}$ & $\begin{array}{l}\text { globular region of } \\
\text { the H9-type HA }\end{array}$ & DNA & $28 \mathrm{nt}$ & 2011 \\
\hline
\end{tabular}

Table A4. List of aptamers for various other viruses which have not been discussed in this review.

\begin{tabular}{|c|c|c|c|c|c|c|c|c|}
\hline Reference & Virus & Virus Type & $\begin{array}{l}\text { Detection/ } \\
\text { Therapy }\end{array}$ & $\begin{array}{l}\text { Mode of Therapy/ } \\
\text { Detection }\end{array}$ & $\begin{array}{c}\text { Detection } \\
\text { Limit/Binding } \\
\text { Affinity }\end{array}$ & Target & $\begin{array}{l}\text { RNA/ } \\
\text { DNA }\end{array}$ & Size \\
\hline [167] & $\begin{array}{l}\text { Apple stem } \\
\text { pitting virus }\end{array}$ & & Detection & $\begin{array}{c}\text { Molecularly } \\
\text { Imprinted } \\
\text { Polymer Gel Laser } \\
\text { Diffraction Sensor }\end{array}$ & $10 \mathrm{ng} / \mathrm{mL}$ & MT32 protein & DNA & $40 \mathrm{nt}$ \\
\hline$[168]$ & $\begin{array}{l}\text { bovine viral } \\
\text { diarrhea virus }\end{array}$ & BVDV type 1 & Detection & $\begin{array}{l}\text { Gold nano } \\
\text { sandwich sensor }\end{array}$ & 800 copies $/ \mathrm{mL}$ & Whole Virus & DNA & $30 \mathrm{nt}$ \\
\hline [169] & Coronavirus & SARS & Detection & Aptamer on Chip & $0.1 \mathrm{pg} / \mathrm{mL}$ & $\begin{array}{c}\text { nucleocapsid } \\
\text { protein }\end{array}$ & RNA & $92 \mathrm{nt}$ \\
\hline$[170]$ & Norovirus & $\begin{array}{c}\text { Human } \\
\text { noroviruse }\end{array}$ & Detection & ELASA & & $\begin{array}{l}\text { NoV target-the } \mathrm{P} \\
\text { domain protein }\end{array}$ & DNA & \\
\hline$[171]$ & Norovirus & $\begin{array}{l}\text { GII.2 HuNoV } \\
\text { strain, Snow } \\
\text { Mountain } \\
\text { Virus }\end{array}$ & Detection & & $\mathrm{K}_{\mathrm{d}} 191 \mathrm{nM}$ & $\begin{array}{l}\text { Immobilized } \\
\text { SMV }\end{array}$ & DNA & $40 \mathrm{nt}$ \\
\hline$[172]$ & Norovirus & $\begin{array}{l}\text { Murine } \\
\text { Norovirus }\end{array}$ & Detection & $\begin{array}{c}\mathrm{K}_{\mathrm{d}} 290 \mathrm{nM} \\
\text { G-quadruplexes }\end{array}$ & $\begin{array}{c}20 \mathrm{aM} \text { to } 120 \\
\mathrm{aM}\end{array}$ & Viral SELEX & DNA & $40 \mathrm{nt}$ \\
\hline$[173]$ & $\begin{array}{l}\text { Porcine } \\
\text { reproductive } \\
\text { and respiratory } \\
\text { syndrome virus }\end{array}$ & VR-2332 & Detection & $\begin{array}{l}\mathrm{K}_{\mathrm{d}} 2.5 \times 10^{5} \\
\mathrm{TCID}_{50} / \mathrm{mL}\end{array}$ & $\begin{array}{c}\text { In water } 0.1 \times \\
10^{0}-10^{1} \\
\text { TCID }_{50} / \mathrm{mL} \\
\text { Nasal/oral } \\
\text { fluid } 4.8 \times \\
10^{0}-5.0 \times 10^{3} \\
\text { TCID }_{50} / \mathrm{mL}\end{array}$ & Viral SELEX & DNA & $40 \mathrm{nt}$ \\
\hline$[174]$ & Vaccinia virus & & Detection & $\mathrm{K}_{\mathrm{d}} 26.3-40.9 \mathrm{nM}$ & $\begin{array}{l}\text { In water } 60 \\
\text { PFU in } 30 \mu \mathrm{L} \text { in } \\
\text { blood } 150 \text { to } \\
900 \text { PFU }\end{array}$ & Viral SELEX & DNA & \\
\hline$[175]$ & vaccinia virus & & Detection & Impedimetric & $\begin{array}{l}60 \text { virions in a } \\
\text { microliter }\end{array}$ & $\begin{array}{l}\text { Virus Infected } \\
\text { Cell SELEX }\end{array}$ & DNA & $40 \mathrm{nt}$ \\
\hline$[176]$ & $\begin{array}{l}\text { vesicular } \\
\text { stomatitis virus }\end{array}$ & $\begin{array}{l}\text { Oncolytic } \\
\text { Virus }\end{array}$ & Detection & $\begin{array}{l}\text { To protect the } \\
\text { Virus from } \\
\text { Nuetralizing } \\
\text { antibodies }\end{array}$ & $\begin{array}{c}53-86 \% \text { degree } \\
\text { of Protection }\end{array}$ & Viral SELEX & DNA & $40 \mathrm{nt}$ \\
\hline [177] & VSV & $\begin{array}{l}\text { vesicular } \\
\text { stomatitis } \\
\text { virus }\end{array}$ & Detection & $\begin{array}{l}\text { aptamer-based } \\
\text { affinity } \\
\text { chromatography }\end{array}$ & & & & $\begin{array}{l}\text { switchable } \\
\text { aptamers }\end{array}$ \\
\hline
\end{tabular}


Table A4. Cont.

\begin{tabular}{|c|c|c|c|c|c|c|c|c|}
\hline Reference & Virus & Virus Type & $\begin{array}{l}\text { Detection/ } \\
\text { Therapy }\end{array}$ & $\begin{array}{l}\text { Mode of Therapy/ } \\
\text { Detection }\end{array}$ & $\begin{array}{c}\text { Detection } \\
\text { Limit/Binding } \\
\text { Affinity }\end{array}$ & Target & $\begin{array}{l}\text { RNA/ } \\
\text { DNA }\end{array}$ & Size \\
\hline [178] & $\begin{array}{l}\text { Apple stem } \\
\text { pitting virus } \\
\text { isolates }\end{array}$ & & Detection & ELONA & $81 \%$ affinity & $\begin{array}{l}\text { MT32/PSA-H } \\
\text { protein }\end{array}$ & DNA & $20-80 \mathrm{nt}$ \\
\hline [179] & $\begin{array}{l}\text { Bovine Herpes } \\
\text { Virus-1 }\end{array}$ & & $\begin{array}{l}\text { Detection/ } \\
\text { Therapy }\end{array}$ & SELEX & $3.5 \mathrm{nM}$ & $\mathrm{gD}$ protein & DNA & $38-51 \mathrm{nt}$ \\
\hline [180] & Dengue Virus & & Detection & SELEX & & 5'-UTR & RNA & \\
\hline [181] & $\begin{array}{c}\text { Human } \\
\text { Papilloma virus } \\
\text { (HPV) }\end{array}$ & & Detection & SELEX & $10 \mathrm{nM}$ & type 16 VLP & DNA & \\
\hline [182] & Iridovirus & & Detection & ELISA & nmol L ${ }^{-1}$ & & DNA & $71 \mathrm{nt}$ \\
\hline [183] & Parvovirus & & Detection & SELEX & $467 \mathrm{nM}$ & & DNA & $49 \mathrm{nt}$ \\
\hline [184] & $\begin{array}{l}\text { Respiratory } \\
\text { Syncytial Virus } \\
\text { (RSV) }\end{array}$ & & Detection & SELEX & $0.5 \mathrm{nM}$ & $\mathrm{F}$ protein & DNA & $30 \mathrm{nt}$ \\
\hline [185] & Sindbis virus & & Detection & ISH/RT-PCR & High affinity & E2 glycoprotein & RNA & \\
\hline [186] & Alphavirus & TC-83 Virus & Therapy & $\begin{array}{l}\text { Replicon } \\
\text { riobozyme } \\
\text { actuator }\end{array}$ & & Vaccine & RNA & \\
\hline [187] & Coronavirus & SARS & Therapy & $\begin{array}{l}\text { Just binding } \\
\text { studies }\end{array}$ & $\mathrm{K}_{\mathrm{d}} 4-9 \mathrm{nM}$ & $\begin{array}{l}\text { nucleocapsid } \\
\text { protein }\end{array}$ & DNA & $45 \mathrm{nt}$ \\
\hline [188] & Dengue & & Therapy & & & $\begin{array}{l}\text { DENV-2 envelop } \\
\text { protein domain } \\
\text { III (ED3) }\end{array}$ & DNA & $15 \mathrm{nt}$ \\
\hline [189] & Dengue & DENV-2 & Therapy & $\begin{array}{l}\text { Thiolated } \\
\text { aptamers }\end{array}$ & $\mathrm{K}_{\mathrm{d}} 154 \mathrm{nM}$ & $\begin{array}{l}\text { envelope protein } \\
\text { domain III }\end{array}$ & DNA & $24 \mathrm{nt}$ \\
\hline [190] & Ebola & VP35 & Therapy & Inhibition of VP35 & $10-50 \mathrm{nM}$ & Viral Protein 35 & RNA & $45 \mathrm{nt}$ \\
\hline [191] & $\begin{array}{l}\text { foot-and- } \\
\text { mouth disease } \\
\text { virus }\end{array}$ & & Therapy & $\begin{array}{l}\text { GFP tagged } \\
\text { aptamers }\end{array}$ & $375 \mathrm{nM}$ & $\begin{array}{c}\text { RNA-dependent } \\
\text { RNA } \\
\text { polymerase }\end{array}$ & RNA & $30 \mathrm{nt}$ \\
\hline [192] & $\begin{array}{l}\text { Hemorrhagic } \\
\text { Septicemia } \\
\text { Virus }\end{array}$ & & Therapy & & $\begin{array}{c}\text { Viral plaques } \\
\text { were reduced } \\
\text { by } 50 \% \text {, cells } \\
\text { were viable and } \\
\text { healthy }\end{array}$ & Viral SELEX & RNA & $40 \mathrm{nt}$ \\
\hline [193] & $\begin{array}{c}\text { Hirame } \\
\text { Rhabdovirus }\end{array}$ & & Therapy & & $\begin{array}{l}15 \text { - to } 63 \text {-fold } \\
\text { reduction in } \\
\text { plaques }\end{array}$ & Viral SELEX & RNA & $40 \mathrm{nt}$ \\
\hline [194] & HPV & HPV-16 & Therapy & Binding Inhibition & & $\begin{array}{l}\text { HPV-16 E7 } \\
\text { protein }\end{array}$ & RNA & \\
\hline [195] & $\mathrm{HPV}$ & HPV-16 & Therapy & & $\mathrm{K}_{\mathrm{d}}=0.05 \mathrm{pM}$ & HPV-16 L1 VLPs & RNA & $15 \mathrm{nt}$ \\
\hline [196] & HPV & HPV-16 & Therapy & $\begin{array}{l}\text { Internalization of } \\
\text { aptamers }\end{array}$ & $\begin{array}{l}5 \text { fold higher } \\
\text { internalization }\end{array}$ & $\begin{array}{l}\text { HPV-16 E6/E7 } \\
\text { transformed } \\
\text { tonsillar } \\
\text { epithelial cell } \\
\text { SELEX }\end{array}$ & RNA & $30 \mathrm{nt}$ \\
\hline [197] & Iridovirus & $\begin{array}{l}\text { Singapore } \\
\text { grouper }\end{array}$ & Therapy & inhibition & $12.09 \mathrm{nM}$ & $\begin{array}{l}\text { SGIV-infected } \\
\text { GS cells }\end{array}$ & DNA & \\
\hline [198] & Iridovirus & $\begin{array}{l}\text { Singapore } \\
\text { grouper }\end{array}$ & Therapy & $\begin{array}{c}30 \% \text { less mortality } \\
\text { of fish }\end{array}$ & & Whole Virus & DNA & $50 \mathrm{nt}$ \\
\hline [199] & Norovirus & & Therapy & & & $\begin{array}{l}\text { capsid protein } \\
\text { VP1 }\end{array}$ & DNA & $49 \mathrm{nt}$ \\
\hline [200] & rabies & & Therapy & $25-33 \%$ survival & $\mathrm{K}_{\mathrm{d}} 307 \mathrm{nM}$ & $\begin{array}{c}\text { RABV } \\
\text { glycoprotein }\end{array}$ & DNA & $45 \mathrm{nt}$ \\
\hline [201] & rabies & & Therapy & $30-50 \%$ survival & & Cell SELEX & DNA & \\
\hline
\end{tabular}


Table A4. Cont.

\begin{tabular}{|c|c|c|c|c|c|c|c|c|}
\hline Reference & Virus & Virus Type & $\begin{array}{l}\text { Detection/ } \\
\text { Therapy }\end{array}$ & $\begin{array}{c}\text { Mode of Therapy/ } \\
\text { Detection }\end{array}$ & $\begin{array}{c}\text { Detection } \\
\text { Limit/Binding } \\
\text { Affinity }\end{array}$ & Target & $\begin{array}{l}\text { RNA/ } \\
\text { DNA }\end{array}$ & Size \\
\hline [202] & rabies & & Therapy & $\begin{array}{c}4 \text { nmol PEG-FO24 } \\
\text { protected } 87.5 \%\end{array}$ & & $\begin{array}{c}\text { RABV-infected } \\
\text { BHK-21 }\end{array}$ & DNA & $45 \mathrm{nt}$ \\
\hline [203] & rabies & & Therapy & & $\mathrm{K}_{\mathrm{d}} 28-39 \mathrm{nM}$ & $\begin{array}{l}\text { Virus infected } \\
\text { Cell SELEX }\end{array}$ & DNA & $45 \mathrm{nt}$ \\
\hline [204] & $\begin{array}{l}\text { Rift Valley } \\
\text { fever virus }\end{array}$ & & Therapy & & & $\begin{array}{l}\text { nucleocapsid } \\
\text { protein }\end{array}$ & RNA & $30 \mathrm{nt}$ \\
\hline [205] & $\begin{array}{c}\text { xenotropic } \\
\text { murine } \\
\text { leukemia } \\
\text { virus-related } \\
\text { virus (XMRV) }\end{array}$ & $\begin{array}{c}\text { Different from } \\
\text { HIV-1 }\end{array}$ & Therapy & $\mathrm{IC}_{50} 2 \mathrm{nM}$ & & XMRV RT & RNA & $\begin{array}{c}\text { three } 12 \\
\text { nt se- } \\
\text { quences }\end{array}$ \\
\hline
\end{tabular}

Table A5. List of companies offering various aptamer-based services. All the data presented here has been collected from the respective company websites.

\begin{tabular}{|c|c|c|c|c|c|c|}
\hline Company & $\begin{array}{l}\text { Custom } \\
\text { Aptamers }\end{array}$ & $\begin{array}{l}\text { SELEX } \\
\text { Kits }\end{array}$ & $\begin{array}{l}\text { Catalogue } \\
\text { Aptamers }\end{array}$ & $\begin{array}{l}\text { Random DNA } \\
\text { Library }\end{array}$ & $\begin{array}{l}\text { Clinical } \\
\text { Trials }\end{array}$ & Country \\
\hline $\begin{array}{l}\text { IDT, } 1710 \text { Commercial Park, Coralville, } \\
\text { Iowa 52241, USA }\end{array}$ & No & No & No & Yes & No & USA \\
\hline $\begin{array}{c}\text { AMSBio, } 1035 \text { Cambridge St Ste 16B, } \\
\text { Cambridge, Massachusetts 02141-1154, } \\
\text { USA }\end{array}$ & Yes & Yes & No & Yes & No & Spain \\
\hline $\begin{array}{l}\text { Gene Link, Inc. } 8 \text { Westchester Plaza, Suite } \\
\text { 130, Elmsford, NY 10523, USA }\end{array}$ & Yes & No & No & Yes & No & USA \\
\hline $\begin{array}{l}\text { Roboklon, Robert-Rössle-Str. 10, } 13125 \\
\text { Berlin, Germany }\end{array}$ & Yes & Yes & No & Yes & No & Germany \\
\hline $\begin{array}{c}\text { Ambiotech, } 225 \text { Broadway, \#1903, New } \\
\text { York, NY 10007, USA }\end{array}$ & Yes & Yes & No & Yes & No & USA \\
\hline $\begin{array}{l}\text { Jena Bioscience, Löbstedter Str. 71, } 07749 \\
\text { Jena, Deutschland }\end{array}$ & Yes & No & No & Yes & No & Germany \\
\hline $\begin{array}{l}\text { TriLink, } 10770 \text { Wateridge Cir Ste 200, San } \\
\text { Diego, CA 92121, USA }\end{array}$ & Yes & Yes & No & Yes & No & USA \\
\hline $\begin{array}{l}\text { IBA Lifesciences, Rudolf-Wissell-Str. 28, } \\
37079 \text { Göttingen, Germany }\end{array}$ & Yes & No & No & Yes & No & Germany \\
\hline Neoventures, 516 Colborne St, London ON & Yes & No & No & Yes & No & Canada \\
\hline OTC Biotech, San Antonio, Texas, USA & Yes & No & Yes & Yes & No & USA \\
\hline $\begin{array}{l}\text { Aptagen, Aptagen, LLC, } 250 \text { North Main } \\
\text { Street, Jacobus, PA 17407, USA }\end{array}$ & Yes & No & Yes & Yes & No & USA \\
\hline $\begin{array}{l}\text { BasePair Technologies, } 415 \text { Madison Ave fl } \\
\text { 4, New York, NY 10017, USA }\end{array}$ & Yes & No & Yes & Yes & No & USA \\
\hline $\begin{array}{l}\text { AptiSci, } 301 \text { Ho, } 3 \text { Dong, Pangyo Seven } \\
\text { Venture Valley, Republic of Korea }\end{array}$ & Yes & No & Yes & Yes & No & South Korea \\
\hline $\begin{array}{l}\text { CamBio, } 1 \text { The Irwin Centre, Scotland } \\
\text { Road, Dry Drayton, Cambridge, UK }\end{array}$ & No & No & $\begin{array}{l}\text { From BasePair } \\
\text { Technologies }\end{array}$ & Yes & No & UK \\
\hline $\begin{array}{l}\text { SomaLogic, } 2945 \text { Wilderness Pl. Boulder, } \\
\text { CO 80301, USA }\end{array}$ & No & No & No & No & Yes & USA \\
\hline $\begin{array}{l}\text { Noxxon Pharma AG, Max-Dohrn-Strasse } \\
8-10,10589 \text { Berlin, Germany }\end{array}$ & No & No & No & No & Yes & Germany \\
\hline $\begin{array}{l}\text { Gilead Sciences, Inc. } 333 \text { Lakeside Drive, } \\
\text { Foster City, CA 94404, USA }\end{array}$ & No & No & No & No & Yes & USA \\
\hline $\begin{array}{c}\text { Sangon Biotech, } 698 \text { Xiangyu Road, } \\
\text { Songjiang District, Shanghai Zip Code: } \\
201611\end{array}$ & No & No & No & Yes & No & China \\
\hline
\end{tabular}


Table A5. Cont.

\begin{tabular}{|c|c|c|c|c|c|c|}
\hline Company & $\begin{array}{l}\text { Custom } \\
\text { Aptamers }\end{array}$ & $\begin{array}{l}\text { SELEX } \\
\text { Kits }\end{array}$ & $\begin{array}{l}\text { Catalogue } \\
\text { Aptamers }\end{array}$ & $\begin{array}{l}\text { Random DNA } \\
\text { Library }\end{array}$ & $\begin{array}{l}\text { Clinical } \\
\text { Trials }\end{array}$ & Country \\
\hline $\begin{array}{c}\text { Takara Bio Inc, } 2560 \text { Orchard Parkway, San } \\
\text { Jose, CA 95131, USA }\end{array}$ & No & No & No & Yes & No & China \\
\hline $\begin{array}{c}\text { AptaRes AG, Am Scheunenviertel 1, } 15749 \\
\text { Mittenwalde, Germany }\end{array}$ & No & No & No & Yes & No & Germany \\
\hline $\begin{array}{l}\text { Bioneer, Inc. } 155 \text { Filbert St, Ste. 216, } \\
\text { Oakland, CA 94607, USA }\end{array}$ & No & No & No & Yes & No & USA \\
\hline Sigma Aldrich, St. Louis, MO 68178, USA & No & No & No & Yes & No & USA \\
\hline
\end{tabular}

\section{References}

1. Ellington, A.D.; Szostak, J.W. In vitro selection of RNA molecules that bind specific ligands. Nature 1990, 346, 818-822. [CrossRef]

2. Irvine, D.; Tuerk, C.; Gold, L. Selexion. Systematic evolution of ligands by exponential enrichment with integrated optimization by non-linear analysis. J. Mol. Biol. 1991, 222, 739-761. [CrossRef]

3. Meng, H.-M.; Fu, T.; Zhang, X.-B.; Tan, W. Cell-SELEX-based aptamer-conjugated nanomaterials for cancer diagnosis and therapy. Natl. Sci. Rev. 2015, 2, 71-84. [CrossRef]

4. Silha, J.V.; Murphy, L.J. The effects of the insulin-like growth factor-I aptamer, NBI-31772, on glucose homeostasis in the mouse. Can. J. Physiol. Pharmacol. 2005, 83, 557-563. [CrossRef]

5. Nakamura, Y. Aptamer: Biology to applications. In Polydiacetylenes; Springer Science and Business Media LLC: Berlin/Heidelberg, Germany, 2011; pp. 135-152.

6. Gedi, V.; Kim, Y.-P. Detection and characterization of cancer cells and pathogenic bacteria using aptamer-based nano-conjugates. Sensors 2014, 14, 18302-18327. [CrossRef] [PubMed]

7. Zhu, Y.; Lü, Y.-H.; Yang, H.-Y.; Lin, J.-S.; Wang, Q.-Z. Recent progress of the aptamer-based antiviral drugs. Yao Xue Xue Bao Acta Pharm. Sin. 2013, 48, 447-456.

8. Wilen, C.B.; Tilton, J.C.; Doms, R.W. HIV: Cell binding and entry. Cold Spring Harb. Perspect. Med. 2012, 2, a006866. [CrossRef]

9. Chan, D.C.; Fass, D.; Berger, J.M.; Kim, P.S. Core structure of gp41 from the HIV envelope glycoprotein. Cell 1997, 89, 263-273. [CrossRef]

10. Bugatti, A.; Giagulli, C.; Urbinati, C.; Caccuri, F.; Chiodelli, P.; Oreste, P.; Fiorentini, S.; Orro, A.; Milanesi, L.; D’Ursi, P.; et al. Molecular interaction studies of HIV-1 matrix protein p17 and heparin: Identification of the heparin-binding motif of p17 as a target for the development of multitarget antagonists. J. Biol. Chem. 2012, 288, 1150-1161. [CrossRef] [PubMed]

11. Cunningham, A.L.; Donaghy, H.; Harman, A.N.; Kim, M.; Turville, S.G. Manipulation of dendritic cell function by viruses. Curr. Opin. Microbiol. 2010, 13, 524-529. [CrossRef] [PubMed]

12. Huang, C.; Tang, M.; Zhang, M.; Majeed, S.; Montabana, E.; Stanfield, R.L.; Dimitrov, D.S.; Korber, B.; Sodroski, J.; Wilson, I.A.; et al. Structure of a V3-containing HIV-1 gp120 core. Science 2005, 310, 1025-1028. [CrossRef] [PubMed]

13. Huang, C.; Lam, S.N.; Acharya, P.; Tang, M.; Xiang, S.; Hussan, S.S.; Stanfield, R.L.; Robinson, J.; Sodroski, J.; Wilson, I.A.; et al. Structures of the CCR5 N terminus and of a tyrosine-sulfated antibody with HIV-1 gp120 and CD4. Science 2007, 317, 1930-1934. [CrossRef] [PubMed]

14. Mushahwar, I.K. Human immunodeficiency viruses: Molecular virology, pathogenesis, diagnosis and treatment. Perspect. Med Virol. 2006, 13, 75-87. [CrossRef]

15. Zhou, J.; Shu, Y.; Guo, P.; Smith, D.D.; Rossi, J.J. Dual functional RNA nanoparticles containing phi29 motor pRNA and anti-gp120 aptamer for cell-type specific delivery and HIV-1 inhibition. Methods 2011, 54, 284-294. [CrossRef]

16. Zhou, J.; Neff, C.P.; Swiderski, P.; Li, H.; Smith, D.D.; Aboellail, T.; Remling-Mulder, L.; Akkina, R.; Rossi, J.J. Functional in vivo delivery of multiplexed anti-HIV-1 siRNAs via a chemically synthesized aptamer with a sticky bridge. Mol. Ther. 2013, 21, 192-200. [CrossRef]

17. Zhou, J.; Rossi, J.J. Aptamer-targeted RNAi for HIV-1 therapy. Methods Mol. Biol. 2011, 721, 355-371. [CrossRef]

18. Wheeler, L.A.; Trifonova, R.; Vrbanac, V.; Basar, E.; McKernan, S.; Xu, Z.; Seung, E.; Deruaz, M.; Dudek, T.; Einarsson, J.I.; et al. Inhibition of HIV transmission in human cervicovaginal explants and humanized mice using CD4 aptamer-siRNA chimeras. $J$. Clin. Investig. 2011, 121, 2401-2412. [CrossRef]

19. Wheeler, L.A.; Vrbanac, V.; Trifonova, R.; Brehm, M.A.; Gilboa-Geffen, A.; Tanno, S.; Greiner, D.L.; Luster, A.D.; Tager, A.M.; Lieberman, J. Durable knockdown and protection from HIV transmission in humanized mice treated with gel-formulated CD4 aptamer-siRNA chimeras. Mol. Ther. 2013, 21, 1378-1389. [CrossRef]

20. Mufhandu, H.T.; Gray, E.S.; Madiga, M.C.; Tumba, N.; Alexandre, K.B.; Khoza, T.; Wibmer, C.K.; Moore, P.L.; Morris, L.; Khati, M. UCLA1, a synthetic derivative of a gp120 RNA aptamer, inhibits entry of human immunodeficiency virus type 1 subtype C. J. Virol. 2012, 86, 4989-4999. [CrossRef] [PubMed]

21. Lopes de Campos, W.R.; Chirwa, N.; London, G.; Rotherham, L.S.; Morris, L.; Mayosi, B.M.; Khati, M. HIV-1 subtype C unproductively infects human cardiomyocytes in vitro and induces apoptosis mitigated by an anti-gp120 aptamer. PLoS ONE 2014, 9, e110930. [CrossRef] 
22. London, G.M.; Mayosi, B.M.; Khati, M. Isolation and characterization of 2'-F-RNA aptamers against whole HIV-1 subtype C envelope pseudovirus. Biochem. Biophys. Res. Commun. 2015, 456, 428-433. [CrossRef]

23. Musumeci, D.; Riccardi, C.; Montesarchio, D. G-quadruplex forming oligonucleotides as anti-HIV agents. Molecules 2015, 20, 17511-17532. [CrossRef] [PubMed]

24. Métifiot, M.; Amrane, S.; Litvak, S.; Andreola, M. G-quadruplexes in viruses: Function and potential therapeutic applications. Nucleic Acids Res. 2014, 42, 12352-12366. [CrossRef] [PubMed]

25. Wyatt, J.R.; Vickers, T.A.; Roberson, J.L.; Buckheit, R.W.; Klimkait, T.; DeBaets, E.; Davis, P.W.; Rayner, B.; Imbach, J.L.; Ecker, D.J. Combinatorially selected guanosine-quartet structure is a potent inhibitor of human immunodeficiency virus envelope-mediated cell fusion. Proc. Natl. Acad. Sci. USA 1994, 91, 1356-1360. [CrossRef]

26. Koizumi, M.; Koga, R.; Hotoda, H.; Momota, K.; Ohmine, T.; Furukawa, H.; Agatsuma, T.; Nishigaki, T.; Abe, K.; Kosaka, T.; et al. Biologically active oligodeoxyribonucleotides-IX.1 synthesis and anti-HIV-1 activity of hexadeoxyribonucleotides, TGGGAG, bearing 3'- and 5'-end-modification. Bioorganic Med. Chem. 1997, 5, 2235-2243. [CrossRef]

27. Hotoda, H.; Koizumi, M.; Koga, R.; Kaneko, M.; Momota, K.; Ohmine, T.; Furukawa, H.; Agatsuma, T.; Nishigaki, T.; Sone, J.; et al. Biologically active oligodeoxyribonucleotides. 5. 5'-end-substituted d(TGGGAG) possesses anti-human immunodeficiency virus type 1 activity by forming a G-quadruplex structure. J. Med. Chem. 1998, 41, 3655-3663. [CrossRef]

28. D'Onofrio, J.; Petraccone, L.; Erra, E.; Martino, L.; Di Fabio, G.; de Napoli, L.; Giancola, C.; Montesarchio, D. 5'-modified G-quadruplex forming oligonucleotides endowed with anti-HIV activity: Synthesis and biophysical properties. Bioconjugate Chem. 2007, 18, 1194-1204. [CrossRef]

29. D'Onofrio, J.; Petraccone, L.; Martino, L.; Di Fabio, G.; Iadonisi, A.; Balzarini, J.; Giancola, C.; Montesarchio, D. Synthesis, biophysical characterization, and anti-HIV activity of glyco-conjugated G-quadruplex-forming oligonucleotides. Bioconjugate Chem. 2008, 19, 607-616. [CrossRef]

30. Di Fabio, G.; D’Onofrio, J.; Chiapparelli, M.; Hoorelbeke, B.; Montesarchio, D.; Balzarini, J.; Napoli, L.D. Discovery of novel anti-HIV active G-quadruplex-forming oligonucleotides. Chem. Commun. 2011, 47, 2363-2365. [CrossRef] [PubMed]

31. Romanucci, V.; Gaglione, M.; Messere, A.; Potenza, N.; Zarrelli, A.; Noppen, S.; Liekens, S.; Balzarini, J.; Di Fabio, G. Hairpin oligonucleotides forming G-quadruplexes: New aptamers with anti-HIV activity. Eur. J. Med. Chem. 2014, 89, 51-58. [CrossRef] [PubMed]

32. Romanucci, V.; Milardi, D.; Campagna, T.; Gaglione, M.; Messere, A.; D’Urso, A.; Crisafi, E.; la Rosa, C.; Zarrelli, A.; Balzarini, J.; et al. Synthesis, biophysical characterization and anti-HIV activity of d(TG 3AG) quadruplexes bearing hydrophobic tails at the $5^{\prime}$-end. Bioorg. Med. Chem. 2014, 22, 960-966. [CrossRef]

33. D'Atri, V.; Oliviero, G.; Amato, J.; Borbone, N.; D’Errico, S.; Mayol, L.; Piccialli, V.; Haider, S.; Hoorelbeke, B.; Balzarini, J.; et al. New anti-HIV aptamers based on tetra-end-linked DNA G-quadruplexes: Effect of the base sequence on anti-HIV activity. Chem. Commun. 2012, 48, 9516-9518. [CrossRef]

34. Nici, F.; Oliviero, G.; Falanga, A.P.; D’Errico, S.; Marzano, M.; Musumeci, D.; Montesarchio, D.; Noppen, S.; Pannecouque, C.; Piccialli, G. Anti-HIV activity of new higher order G-quadruplex aptamers obtained from tetra-end-linked oligonucleotides. Org. Biomol. Chem. 2018, 16, 2349-2355. [CrossRef] [PubMed]

35. Virgilio, A.; Esposito, V.; Citarella, G.; Mayol, L.; Galeone, A. Structural investigations on the anti-HIV G-quadruplex-forming oligonucleotide TGGGAG and its analogues: Evidence for the presence of an A-tetrad. ChemBioChem 2012, 13, 2219-2224. [CrossRef] [PubMed]

36. Lange, M.J.; Sharma, T.K.; Whatley, A.S.; Landon, L.A.; Tempesta, M.A.; Johnson, M.C.; Burke, D.H. Robust suppression of HIV replication by intracellularly expressed reverse transcriptase aptamers is independent of ribozyme processing. Mol. Ther. 2012, 20, 2304-2314. [CrossRef]

37. Ditzler, M.A.; Bose, D.; Shkriabai, N.; Marchand, B.; Sarafianos, S.G.; Kvaratskhelia, M.; Burke, D.H. Broad-spectrum aptamer inhibitors of HIV reverse transcriptase closely mimic natural substrates. Nucleic Acids Res. 2011, 39, 8237-8247. [CrossRef] [PubMed]

38. Whatley, A.S.; Ditzler, M.A.; Lange, M.J.; Biondi, E.; Sawyer, A.W.; Chang, J.L.; Franken, J.D.; Burke, D.H. Potent inhibition of HIV-1 reverse transcriptase and replication by nonpseudoknot, "UCAA-motif” RNA aptamers. Mol. Ther. Nucl. Acids 2013,2 , e71. [CrossRef]

39. Lange, M.J.; Burke, D.H. Screening inhibitory potential of anti-HIV RT RNA aptamers. Methods Mol. Biol. 2014, 1103, 11-29.

40. Ruslinda, A.R.; Wang, X.; Ishii, Y.; Ishiyama, Y.; Tanabe, K.; Kawarada, H. Human immunodeficiency virus trans-activator of transcription peptide detection via ribonucleic acid aptamer on aminated diamond biosensor. Appl. Phys. Lett. 2011, $99,123702$. [CrossRef]

41. Ruslinda, A.R.; Tanabe, K.; Ibori, S.; Wang, X.; Kawarada, H. Effects of diamond-FET-based RNA aptamer sensing for detection of real sample of HIV-1 tat protein. Biosens Bioelectron. 2013, 40, 277-282. [CrossRef]

42. Liang, Y.; Zhang, Z.; Wei, H.; Hu, Q.; Deng, J.; Guo, D.; Cui, Z.; Zhang, X.-E. Aptamer beacons for visualization of endogenous protein HIV-1 reverse transcriptase in living cells. Biosens. Bioelectron. 2011, 28, 270-276. [CrossRef]

43. Kim, M.-G.; Shon, Y.; Lee, J.; Byun, Y.; Choi, B.-S.; Kim, Y.B.; Oh, Y.-K. Double stranded aptamer-anchored reduced graphene oxide as target-specific nano detector. Biomaterials 2014, 35, 2999-3004. [CrossRef]

44. Niedzwiecki, D.J.; Iyer, R.; Borer, P.N.; Movileanu, L. Sampling a biomarker of the human immunodeficiency virus across a synthetic nanopore. ACS Nano 2013, 7, 3341-3350. [CrossRef] [PubMed] 
45. Ivanov, Y.D.; Bukharina, N.S.; Pleshakova, T.O.; Frantsuzov, P.A.; Andreeva, E.Y.; Kaysheva, A.L.; Zgoda, V.G.; Izotov, A.A.; Pavlova, T.I.; Ziborov, V.S.; et al. Atomic force microscopy fishing and mass spectrometry identification of gp120 on immobilized aptamers. Int. J. Nanomed. 2014, 9, 4659-4670. [CrossRef]

46. Wang, Y.; Bai, X.; Wen, W.; Zhang, X.; Wang, S. Ultrasensitive electrochemical biosensor for HIV gene detection based on graphene stabilized gold nanoclusters with exonuclease amplification. ACS Appl. Mater. Interfaces 2015, 7, 18872-18879. [CrossRef] [PubMed]

47. Ferreira-Bravo, I.A.; Cozens, C.; Holliger, P.; DeStefano, J.J. Selection of 2'-deoxy-2'-fluoroarabinonucleotide (FANA) aptamers that bind HIV-1 reverse transcriptase with picomolar affinity. Nucleic Acids Res. 2015, 43, 9587-9599. [CrossRef]

48. Esposito, V.; Pirone, L.; Mayol, L.; Pedone, E.; Virgilio, A.; Galeone, A. Exploring the binding of d(GGGT)4 to the HIV-1 integrase: An approach to investigate G-quadruplex aptamer/target protein interactions. Biochimie 2016, 127, 19-22. [CrossRef]

49. Mufhandu, H.T.; Alexandre, K.B.; Gray, E.S.; Morris, L.; Khati, M. UCLA1 aptamer inhibition of human immunodeficiency virus type 1 subtype C primary isolates in macrophages and selection of resistance. Biochem. Biophys. Rep. 2016, 7, 408-414. [CrossRef]

50. Lange, M.J.; Nguyen, P.D.M.; Callaway, M.K.; Johnson, M.C.; Burke, D.H. RNA-protein interactions govern antiviral specificity and encapsidation of broad spectrum anti-HIV reverse transcriptase aptamers. Nucleic Acids Res. 2017, 45, 6087-6097. [CrossRef]

51. Prokofjeva, M.; Tsvetkov, V.; Basmanov, D.; Varizhuk, A.; Lagarkova, M.; Smirnov, I.; Prusakov, K.; Klinov, D.; Prassolov, V.; Pozmogova, G.; et al. Anti-HIV activities of intramolecular G4 and non-G4 oligonucleotides. Nucleic Acid Ther. 2017, $27,56-66$. [CrossRef]

52. Yamaoki, Y.; Nagata, T.; Mashima, T.; Katahira, M. Development of an RNA aptamer that acquires binding capacity against HIV-1 tat protein: Via G-quadruplex formation in response to potassium ions. Chem. Commun. 2017, 53, 7056-7059. [CrossRef]

53. Métifiot, M.; Amrane, S.; Mergny, J.-L.; Andreola, M.-L. Anticancer molecule AS1411 exhibits low nanomolar antiviral activity against HIV-1. Biochimie 2015, 118, 173-175. [CrossRef]

54. Catuogno, S.; Esposito, C.L.; de Franciscis, V. A trojan horse for human immunodeficiency virus. Chem. Biol. 2015, 22, 313-314. [CrossRef]

55. Duclair, S.; Gautam, A.; Ellington, A.; Prasad, V.R. High-affinity RNA aptamers against the HIV-1 protease inhibit both in vitro protease activity and late events of viral replication. Mol. Ther. Nucl. Acids 2015, 4, e228. [CrossRef]

56. Takahashi, M.; Burnett, J.C.; Rossi, J.J. Aptamer-siRNA chimeras for HIV. Adv. Exp. Med. Biol. 2015, 848, 211-234. [CrossRef] [PubMed]

57. Sánchez-Luque, F.J.; Stich, M.; Manrubia, S.; Briones, C.; Berzal-Herranz, A. Efficient HIV-1 inhibition by a 16 nt-long RNA aptamer designed by combining in vitro selection and in silico optimisation strategies. Sci. Rep. 2014, 4, srep06242. [CrossRef] [PubMed]

58. Zhao, N.; Pei, S.-N.; Parekh, P.; Salazar, E.; Zu, Y. Blocking interaction of viral gp120 and CD4-expressing T cells by single-stranded DNA aptamers. Int. J. Biochem. Cell Biol. 2014, 51, 10-18. [CrossRef] [PubMed]

59. Shiang, Y.-C.; Ou, C.-M.; Chen, S.-J.; Ou, T.-Y.; Lin, H.-J.; Huang, C.-C.; Chang, H.-T. Highly efficient inhibition of human immunodeficiency virus type 1 reverse transcriptase by aptamers functionalized gold nanoparticles. Nanoscale 2013, 5, $2756-2764$. [CrossRef]

60. Xu, L.; Cai, L.; Chen, X.; Jiang, X.; Chong, H.; Zheng, B.; Wang, K.; He, J.; Chen, W.; Zhang, T.; et al. DNA duplexes with hydrophobic modifications inhibit fusion between HIV-1 and cell membranes. Antimicrob. Agents Chemother. 2013, 57, 4963-4970 [CrossRef]

61. Zhan, S.B.; Zhang, X.G.; Li, H.X.; Zeng, Y. A novel SELEX method for screening of HIV-1 P24 antigen. Zhonghua Shi Yan He Lin Chuang Bing Du Xue Za Zhi 2013, 27, 218-220.

62. Possik, E.J.; Bou Sleiman, M.S.; Ghattas, I.R.; Smith, C.A. Randomized codon mutagenesis reveals that the HIV rev arginine-rich motif is robust to substitutions and that double substitution of two critical residues alters specificity. J. Mol. Recognit. 2013, 26, 286-296. [CrossRef]

63. Magbanua, E.; Zivkovic, T.; Hansen, B.; Beschorner, N.; Meyer, C.; Lorenzen, I.; Grötzinger, J.; Hauber, J.; Torda, A.E.; Mayer, G.; et al. D(GGGT)4 and r(GGGU)4 are both HIV-1 inhibitors and interleukin-6 receptor aptamers. RNA Biology 2013, 10, $216-227$. [CrossRef]

64. Zhu, Q.; Shibata, T.; Kabashima, T.; Kai, M. Inhibition of HIV-1 protease expression in T cells owing to DNA aptamer-mediated specific delivery of siRNA. Eur. J. Med. Chem. 2012, 56, 396-399. [CrossRef]

65. Scheideman, E.H.; Marlatt, S.A.; Xie, Y.; Hu, Y.; Sutton, R.E.; Dimaio, D. Transmembrane protein aptamers that inhibit CCR5 expression and HIV coreceptor function. J. Virol. 2012, 86, 10281-10292. [CrossRef]

66. Um, H.-J.; Kim, M.; Lee, S.-H.; Kim, Y.-H. Preventing the formation of positive transcription elongation factor $b$ by human cyclin T1-binding RNA aptamer for anti-HIV transcription. AIDS 2012, 26, 1599-1605. [CrossRef]

67. Lai, Y.-T.; DeStefano, J.J. A primer-free method that selects high-affinity single-stranded DNA aptamers using thermostable RNA ligase. Anal. Biochem. 2011, 414, 246-253. [CrossRef] [PubMed]

68. Faure-Perraud, A.; Métifiot, M.; Reigadas, S.; Recordon-Pinson, P.; Parissi, V.; Ventura, M.; Andréola, M.-L. The guaninequadruplex aptamer 93del inhibits HIV-1 replication ex vivo by interfering with viral entry, reverse transcription and integration. Antivir. Ther. 2011, 16, 383-394. [CrossRef] [PubMed]

69. Zhou, J.; Satheesan, S.; Li, H.; Weinberg, M.S.; Morris, K.V.; Burnett, J.C.; Rossi, J.J. Cell-specific RNA aptamer against human CCR5 specifically targets HIV-1 susceptible cells and inhibits HIV-1 infectivity. Chem. Biol. 2015, 22, 379-390. [CrossRef] [PubMed] 
70. Neff, C.P.; Zhou, J.; Remling, L.; Kuruvilla, J.; Zhang, J.; Li, H.; Smith, D.D.; Swiderski, P.; Rossi, J.J.; Akkina, R. An aptamer-siRNA chimera suppresses HIV-1 viral loads and protects from helper $\mathrm{CD}^{+}{ }^{+} \mathrm{T}$ cell decline in humanized mice. Sci. Transl. Med. 2011, 3, 66ra6. [CrossRef]

71. Ramalingam, D.; Duclair, S.; Datta, S.A.K.; Ellington, A.; Rein, A.; Prasad, V.R. RNA aptamers directed to human immunodeficiency virus type 1 gag polyprotein bind to the matrix and nucleocapsid domains and inhibit virus production. J. Virol. 2011, 85, 305-314. [CrossRef] [PubMed]

72. Watashi, K.; Urban, S.; Li, W.; Wakita, T. NTCP and beyond: Opening the door to unveil hepatitis B virus entry. Int. J. Mol. Sci. 2014, 15, 2892-2905. [CrossRef]

73. World Health Organization (WHO). Hepatits. Available online: http://www.who.int/csr/disease/hepatitis/whocdscsrlyo20022 /en/index8.html\#23 (accessed on 20 April 2015).

74. Yan, H.; Zhong, G.; Xu, G.; He, W.; Jing, Z.; Gao, Z.; Huang, Y.; Qi, Y.; Peng, B.; Wang, H.; et al. Sodium taurocholate cotransporting polypeptide is a functional receptor for human hepatitis B and D virus. eLife 2012, 1, e00049. [CrossRef]

75. Gao, W.; Hu, J. Formation of hepatitis B virus covalently closed circular DNA: Removal of genome-linked protein. J. Virol. 2007, 81, 6164-6174. [CrossRef]

76. Lindenbach, B.D.; Rice, C.M. The ins and outs of hepatitis C virus entry and assembly. Nat. Rev. Microbiol. 2013, 11, 688-700. [CrossRef] [PubMed]

77. André, P.; Pradel, F.; Deforges, S.; Perret, M.; Berland, J.-L.; Sodoyer, M.; Pol, S.; Bréchot, C.; Paranhos-Baccalà, G.; Lotteau, V. Characterization of low- and very-low-density hepatitis C virus RNA-containing particles. J. Virol. 2002, 76, 7040-7048. [CrossRef]

78. Blanchard, E.; Belouzard, S.; Goueslain, L.; Wakita, T.; Dubuisson, J.; Wychowski, C.; Rouillé, Y. Hepatitis C virus entry depends on clathrin-mediated endocytosis. J. Virol. 2006, 80, 6964-6972. [CrossRef]

79. Zhu, Y.; Qian, X.; Zhao, P.; Qi, Z. How hepatitis C virus invades hepatocytes: The mystery of viral entry. World J. Gastroenterol. 2014, 20, 3457-3467. [CrossRef] [PubMed]

80. Coller, K.E.; Heaton, N.S.; Berger, K.L.; Cooper, J.D.; Saunders, J.L.; Randall, G. Molecular determinants and dynamics of hepatitis C virus secretion. PLoS Pathog. 2012, 8, e1002466. [CrossRef] [PubMed]

81. Feng, H.; Beck, J.; Nassal, M.; Hu, K.-H. A SELEX-screened aptamer of human hepatitis B virus RNA encapsidation signal suppresses viral replication. PLOS ONE 2011, 6, e27862. [CrossRef] [PubMed]

82. Chen, A.; T-Thienprasert, N.P.; Brown, C.M. Prospects for inhibiting the post-transcriptional regulation of gene expression in hepatitis B virus. World J. Gastroenterol. 2014, 20, 7993-8004. [CrossRef]

83. Zhang, Z.; Zhang, J.; Pei, X.; Zhang, Q.; Lu, B.; Zhang, X.; Liu, J. An aptamer targets HBV core protein and suppresses HBV replication in HepG2.2.15 cells. Int. J. Mol. Med. 2014, 34, 1423-1429. [CrossRef]

84. Orabi, A.; Bieringer, M.; Geerlof, A.; Bruss, V. An aptamer against the matrix binding domain on the hepatitis B virus capsid impairs virion formation. J. Virol. 2015, 89, 9281-9287. [CrossRef]

85. Marton, S.; Berzal-Herranz, B.; Garmendia, E.; Cueto, F.J.; Berzal-Herranz, A. Anti-HCV RNA aptamers targeting the genomic cis-acting replication element. Pharmaceuticals 2011, 5, 49-60. [CrossRef] [PubMed]

86. Romero-López, C.; Berzal-Herranz, B.; Gómez, J.; Berzal-Herranz, A. An engineered inhibitor RNA that efficiently interferes with hepatitis C virus translation and replication. Antivir. Res. 2012, 94, 131-138. [CrossRef] [PubMed]

87. Marton, S.; Romero-Lõpez, C.; Berzal-Herranz, A. RNA aptamer-mediated interference of HCV replication by targeting the CRE-5BSL3.2 domain. J. Viral Hepat. 2013, 20, 103-112. [CrossRef] [PubMed]

88. Lee, C.H.; Lee, S.-W. Inhibition of hepatitis C virus (HCV) replication by hammerhead ribozyme which activity can be allosterically regulated by HCV NS5B RNA replicase. Korean J. Microbiol. 2011, 47, 188-193.

89. Lee, C.H.; Kim, J.H.; Lee, S.-W. Prospects for nucleic acid-based therapeutics against hepatitis C virus. World J. Gastroenterol. 2013, 19, 8949-8962. [CrossRef]

90. Lee, C.H.; Lee, S.-H.; Kim, J.H.; Noh, Y.-H.; Noh, G.-J.; Lee, S.-W. Pharmacokinetics of a cholesterol-conjugated aptamer against the hepatitis C virus (HCV) NS5B protein. Mol. Ther. Nucl. Acids 2015, 4, e254. [CrossRef] [PubMed]

91. Lee, C.H.; Lee, Y.J.; Kim, J.H.; Lim, J.H.; Kim, J.-H.; Han, W.; Lee, S.-H.; Noh, G.-J.; Lee, S.-W. Inhibition of hepatitis C virus (HCV) replication by specific RNA aptamers against HCV NS5B RNA replicase. J. Virol. 2013, 87, 7064-7074. [CrossRef]

92. Yang, D.; Meng, X.; Yu, Q.; Xu, L.; Long, Y.; Liu, B.; Fang, X.; Zhu, H. Inhibition of hepatitis C virus infection by DNA aptamer against envelope protein. Antimicrob. Agents Chemother. 2013, 57, 4937-4944. [CrossRef]

93. Delaviz, N.; Gill, P.; Ajami, A.; Aarabi, M. Aptamer-conjugated magnetic nanoparticles for the efficient removal of HCV particles from human plasma samples. RSC Adv. 2015, 5, 79433-79439. [CrossRef]

94. Suh, S.-K.; Song, S.; Oh, H.-B.; Hwang, S.; Hah, S.S. Aptamer-based competitive binding assay for one-step quantitation of hepatitis B surface antigen. Analyst 2014, 139, 4310-4314. [CrossRef]

95. Xi, Z.; Huang, R.; Li, Z.; He, N.; Wang, T.; Su, E.; Deng, Y. Selection of HBsAg-specific DNA aptamers based on carboxylated magnetic nanoparticles and their application in the rapid and simple detection of hepatitis b virus infection. ACS Appl. Mater. Interfaces 2015, 7, 11215-11223. [CrossRef]

96. Roh, C.; Kim, S.E.; Jo, S.-K. Label free inhibitor screening of hepatitis C virus (HCV) NS5B viral protein using RNA oligonucleotide. Sensors 2011, 11, 6685-6696. [CrossRef] [PubMed]

97. Wang, C.; Zhang, L.; Shen, X. Development of a nucleic acid lateral flow strip for detection of hepatitis C virus (HCV) core antigen. Nucleosides Nucleotides Nucleic Acids 2013, 32, 59-68. [CrossRef] [PubMed] 
98. Park, J.H.; Jee, M.H.; Kwon, O.S.; Keum, S.J.; Jang, S.K. Infectivity of hepatitis C virus correlates with the amount of envelope protein E2: Development of a new aptamer-based assay system suitable for measuring the infectious titer of HCV. Virology 2013, 439, 13-22. [CrossRef] [PubMed]

99. Chen, F.; Chen, S.-C.; Zhou, J.; Chen, Z.-D.; Chen, F. Identification of aptamer-binding sites in hepatitis C virus envelope glycoprotein E2. Iran J. Med. Sci. 2015, 40, 63-67. [PubMed]

100. Bang, G.S.; Cho, S.; Lee, N.; Lee, B.-R.; Kim, J.-H.; Kim, B.-G. Rational design of modular allosteric aptamer sensor for label-free protein detection. Biosens. Bioelectron. 2013, 39, 44-50. [CrossRef]

101. Huang, R.; Xi, Z.; Deng, Y.; He, N. Fluorescence based Aptasensors for the determination of hepatitis B virus e antigen. Sci. Rep. 2016, 6, 31103. [CrossRef]

102. Qu, F.; Liu, Y.; Kong, R.; You, J. A versatile DNA detection scheme based on the quenching of fluorescent silver nanoclusters by MoS2nanosheets: Application to aptamer-based determination of hepatitis B virus and of dopamine. Microchim. Acta 2017, 184, 4417-4424. [CrossRef]

103. Liu, G.; Li, J.; Feng, D.-Q.; Zhu, J.-J.; Wang, W. Silver nanoclusters beacon as stimuli-responsive versatile platform for multiplex DNAs detection and aptamer-substrate complexes sensing. Anal. Chem. 2017, 89, 1002-1008. [CrossRef]

104. Ghanbari, K.; Roushani, M.; Azadbakht, A. Ultra-sensitive aptasensor based on a GQD nanocomposite for detection of hepatitis C virus core antigen. Anal. Biochem. 2017, 534, 64-69. [CrossRef] [PubMed]

105. Pleshakova, T.O.; Kaysheva, A.L.; Bayzyanova, J.M.; Anashkina, A.S.; Uchaikin, V.F.; Ziborov, V.S.; Konev, V.A.; Archakov, A.I.; Ivanov, Y.D. The detection of hepatitis C virus core antigen using afm chips with immobolized aptamers. J. Virol. Methods 2018, 251, 99-105. [CrossRef]

106. Zhang, Y.; Wang, J.; Cheng, H.; Sun, N.; Liu, M.; Wu, Z.; Pei, R. Inducible Bcl-2 gene RNA interference mediated by aptamerintegrated HDV ribozyme switch. Integr. Biol. 2017, 9, 619-626. [CrossRef]

107. Nomura, Y.; Zhou, L.; Miu, A.; Yokobayashi, Y. Controlling mammalian gene expression by allosteric hepatitis delta virus ribozymes. ACS Synth. Biol. 2013, 2, 684-689. [CrossRef]

108. Gao, Y.; Yu, X.; Xue, B.; Zhou, F.; Wang, X.; Yang, D.; Liu, N.; Xu, L.; Fang, X.; Zhu, H. Inhibition of hepatitis C virus infection by dna aptamer against NS2 protein. PLoS ONE 2014, 9, e90333. [CrossRef]

109. Shi, S.; Yu, X.; Gao, Y.; Xue, B.; Wu, X.; Wang, X.; Yang, D.; Zhu, H. Inhibition of hepatitis C virus production by aptamers against the core protein. J. Virol. 2014, 88, 1990-1999. [CrossRef] [PubMed]

110. Yu, X.; Gao, Y.; Xue, B.; Wang, X.; Yang, D.; Qin, Y.; Yu, R.; Liu, N.; Xu, L.; Fang, X.; et al. Inhibition of hepatitis C virus infection by NS5A-specific aptamer. Antivir. Res. 2014, 106, 116-124. [CrossRef]

111. Rapid Reference Influenza. Available online: http:/ / www.rapidreferenceinfluenza.com/resource-center (accessed on 20 April 2016).

112. Samji, T. Influenza A: Understanding the viral life cycle. Yale J. Biol. Med. 2009, 82, 153-159. [PubMed]

113. Matrosovich, M.; Tuzikov, A.; Bovin, N.; Gambaryan, A.; Klimov, A.; Castrucci, M.R.; Donatelli, I.; Kawaoka, Y. Early alterations of the receptor-binding properties of $\mathrm{H} 1, \mathrm{H} 2$, and $\mathrm{H} 3$ avian influenza virus hemagglutinins after their introduction into mammals. J. Virol. 2000, 74, 8502-8512. [CrossRef]

114. Lakadamyali, M.; Rust, M.J.; Zhuang, X. Endocytosis of influenza viruses. Microbes Infect 2004, 6, 929-936. [CrossRef]

115. Shtyrya, Y.A.; Mochalova, L.V.; Bovin, N.V. Influenza virus neuraminidase: Structure and function. Acta Nat. 2009, 1, $26-32$. [CrossRef]

116. Gopinath, S.C.B.; Kumar, P.K.R. Aptamers that bind to the hemagglutinin of the recent pandemic influenza virus H1N1 and efficiently inhibit agglutination. Acta Biomater. 2013, 9, 8932-8941. [CrossRef] [PubMed]

117. Musafia, B.; Oren-Banaroya, R.; Noiman, S. Designing anti-influenza aptamers: Novel quantitative structure activity relationship approach gives insights into aptamer-Virus interaction. PLoS ONE 2014, 9, e97696. [CrossRef] [PubMed]

118. Wongphatcharachai, M.; Wang, P.; Enomoto, S.; Webby, R.J.; Gramer, M.R.; Amonsin, A.; Sreevatsan, S. Neutralizing DNA aptamers against swine influenza H3N2 viruses. J. Clin. Microbiol. 2013, 51, 46-54. [CrossRef] [PubMed]

119. Woo, H.-M.; Lee, J.-M.; Yim, S.; Jeong, Y.-J. Isolation of single-stranded DNA aptamers that distinguish influenza virus hemagglutinin subtype H1 from H5. PLoS ONE 2015, 10, e0125060. [CrossRef]

120. Suenaga, E.; Kumar, P.K.R. An aptamer that binds efficiently to the hemagglutinins of highly pathogenic avian influenza viruses (H5N1 and H7N7) and inhibits hemagglutinin-glycan interactions. Acta Biomater. 2014, 10, 1314-1323. [CrossRef]

121. Yuan, S.; Zhang, N.; Singh, K.; Shuai, H.; Chu, H.; Zhou, J.; Chow, B.K.C.; Zheng, B.-J. Cross-protection of influenza A virus infection by a DNA aptamer targeting the PA endonuclease domain. Antimicrob. Agents Chemother. 2015, 59, 4082-4093. [CrossRef]

122. Kwon, H.-M.; Lee, K.H.; Han, B.W.; Han, M.R.; Kim, D.H. An RNA aptamer that specifically binds to the glycosylated hemagglutinin of avian influenza virus and suppresses viral infection in cells. PLoS ONE 2014, 9, e97574. [CrossRef]

123. Park, S.Y.; Kim, S.; Yoon, H.; Kim, K.-B.; Kalme, S.S.; Oh, S.; Song, C.S.; Kim, D.-E. Selection of an antiviral RNA aptamer against hemagglutinin of the subtype H5 avian influenza virus. Nucleic Acid Ther. 2011, 21, 395-402. [CrossRef]

124. Choi, S.K.; Lee, C.; Lee, K.S.; Choe, S.-Y.; Mo, I.P.; Seong, R.H.; Hong, S.; Jeon, S.H. DNA aptamers against the receptor binding region of hemagglutinin prevent avian influenza viral infection. Mol. Cells 2011, 32, 527-533. [CrossRef] [PubMed]

125. Zhang, Y.; Yu, Z.; Jiang, F.; Fu, P.; Shen, J.; Wu, W.; Li, J. Two DNA aptamers against avian influenza H9N2 virus prevent viral infection in cells. PLoS ONE 2015, 10, e0123060. [CrossRef] 
126. Bai, H.; Wang, R.; Hargis, B.; Lu, H.; Li, Y. A SPR aptasensor for detection of avian influenza virus H5N1. Sensors 2012, 12, 12506-12518. [CrossRef] [PubMed]

127. Wang, R.; Li, Y. Hydrogel based QCM aptasensor for detection of avian influenza virus. Biosens. Bioelectron. 2013, 42, 148-155. [CrossRef] [PubMed]

128. Wang, R.; Zhao, J.; Jiang, T.; Kwon, Y.M.; Lu, H.; Jiao, P.; Liao, M.; Li, Y. Selection and characterization of DNA aptamers for use in detection of avian influenza virus H5N1. J. Virol. Methods 2013, 189, 362-369. [CrossRef]

129. Fu, Y.; Callaway, Z.; Lum, J.; Wang, R.; Lin, J.; Li, Y. Exploiting enzyme catalysis in ultra-low ion strength media for impedance biosensing of avian influenza virus using a bare interdigitated electrode. Anal. Chem. 2014, 86, 1965-1971. [CrossRef]

130. Wang, R.; Xu, L.; Li, Y. Bio-nanogate controlled enzymatic reaction for virus sensing. Biosens. Bioelectron. 2015, 67, 400-407. [CrossRef]

131. Lum, J.; Wang, R.; Hargis, B.; Tung, S.; Bottje, W.; Lu, H.; Li, Y. An impedance aptasensor with microfluidic chips for specific detection of H5N1 avian influenza virus. Sensors 2015, 15, 18565-18578. [CrossRef]

132. Liu, X.; Cheng, Z.; Fan, H.; Ai, S.; Han, R. Electrochemical detection of avian influenza virus H5N1 gene sequence using a DNA aptamer immobilized onto a hybrid nanomaterial-modified electrode. Electrochim. Acta 2011, 56, 6266-6270. [CrossRef]

133. Diba, F.S.; Kim, S.; Lee, H.J. Amperometric bioaffinity sensing platform for avian influenza virus proteins with aptamer modified gold nanoparticles on carbon chips. Biosens. Bioelectron. 2015, 72, 355-361. [CrossRef] [PubMed]

134. Hushegyi, A.; Pihíková, D.; Bertok, T.; Adam, V.; Kizek, R.; Tkac, J. Ultrasensitive detection of influenza viruses with a glycan-based impedimetric biosensor. Biosens. Bioelectron. 2016, 79, 644-649. [CrossRef]

135. Negri, P.; Chen, G.; Kage, A.; Nitsche, A.; Naumann, D.; Xu, B.; Dluhy, R.A. Direct optical detection of viral nucleoprotein binding to an anti-influenza aptamer. Anal. Chem. 2012, 84, 5501-5508. [CrossRef] [PubMed]

136. Negri, P.; Kage, A.; Nitsche, A.; Naumann, D.; Dluhy, R.A. Detection of viral nucleoprotein binding to anti-influenza aptamers via SERS. Chem. Commun. 2011, 47, 8635-8637. [CrossRef] [PubMed]

137. Lai, H.-C.; Wang, C.-H.; Liou, T.-M.; Lee, G.-B. Influenza A virus-specific aptamers screened by using an integrated microfluidic system. Lab Chip 2014, 14, 2002-2013. [CrossRef] [PubMed]

138. Le, T.T.; Adamiak, B.; Benton, D.J.; Johnson, C.J.; Sharma, S.; Fenton, R.; McCauley, J.W.; Iqbal, M.; Cass, A.E.G. Aptamer-based biosensors for the rapid visual detection of flu viruses. Chem. Commun. 2014, 50, 15533-15536. [CrossRef] [PubMed]

139. Lakshmipriya, T.; Fujimaki, M.; Gopinath, S.C.B.; Awazu, K. Generation of anti-influenza aptamers using the systematic evolution of ligands by exponential enrichment for sensing applications. Langmuir 2013, 29, 15107-15115. [CrossRef] [PubMed]

140. Pang, Y.; Rong, Z.; Wang, J.; Xiao, R.; Wang, S. A fluorescent aptasensor for H5N1 influenza virus detection based-on the core-shell nanoparticles metal-enhanced fluorescence (MEF). Biosens. Bioelectron. 2015, 66, 527-532. [CrossRef] [PubMed]

141. Shiratori, I.; Akitomi, J.; Boltz, D.A.; Horii, K.; Furuichi, M.; Waga, I. Selection of DNA aptamers that bind to influenza A viruses with high affinity and broad subtype specificity. Biochem. Biophys. Res. Commun. 2014, 443, 37-41. [CrossRef]

142. Cui, Z.Q.; Ren, Q.; Wei, H.P.; Chen, Z.; Deng, J.Y.; Zhang, Z.P.; Zhang, X.E. Quantum dot-aptamer nanoprobes for recognizing and labeling influenza A virus particles. Nanoscale 2011, 3, 2454-2457. [CrossRef] [PubMed]

143. Tseng, Y.-T.; Wang, C.-H.; Chang, C.-P.; Lee, G.-B. Integrated microfluidic system for rapid detection of influenza H1N1 virus using a sandwich-based aptamer assay. Biosens. Bioelectron. 2016, 82, 105-111. [CrossRef]

144. Wang, R.; Wang, L.; Callaway, Z.T.; Lu, H.; Huang, T.J.; Li, Y. A nanowell-based QCM aptasensor for rapid and sensitive detection of avian influenza virus. Sens. Actuators B Chem. 2017, 240, 934-940. [CrossRef]

145. Hmila, I.; Wongphatcharachai, M.; Laamiri, N.; Aouini, R.; Marnissi, B.; Arbi, M.; Sreevatsan, S.; Ghram, A. A novel method for detection of H9N2 influenza viruses by an aptamer-real time-PCR. J. Virol. Methods 2017, 243, 83-91. [CrossRef] [PubMed]

146. Le, T.T.; Chang, P.; Benton, D.J.; McCauley, J.W.; Iqbal, M.; Cass, A.E.G. Dual recognition element lateral flow assay toward multiplex strain specific influenza virus detection. Anal. Chem. 2017, 89, 6781-6786. [CrossRef] [PubMed]

147. Pilling, A.; Rosenberg, M.F.; Willis, S.H.; Jäger, J.; Cohen, G.H.; Eisenberg, R.J.; Meredith, D.M.; Holzenburg, A. Three-dimensional structure of herpes simplex virus type 1 glycoprotein D at 2.4-nanometer resolution. J. Virol. 1999, 73, 7830-7834. [CrossRef]

148. Akhtar, J.; Shukla, D. Viral entry mechanisms: Cellular and viral mediators of herpes simplex virus entry. FEBS J 2009, 276, 7228-7236. [CrossRef]

149. Eisenberg, R.J.; Atanasiu, D.; Cairns, T.M.; Gallagher, J.R.; Krummenacher, C.; Cohen, G.H. Herpes virus fusion and entry: A story with many characters. Viruses 2012, 4, 800-832. [CrossRef]

150. Haarr, L.; Skulstad, S. The herpes simplex virus type 1 particle: Structure and molecular functions. APMIS 1994, 102, 321-346. [CrossRef]

151. Liu, Y.; Gong, W.; Huang, C.C.; Herr, W.; Cheng, X. Crystal structure of the conserved core of the herpes simplex virus transcriptional regulatory protein VP16. Genes Dev. 1999, 13, 1692-1703. [CrossRef]

152. Li, M.-L.; Guo, H.; Ding, Q.; Zheng, C.-F. A multiple functional protein: The herpes simplex virus type 1 tegument protein VP22. Virol. Sin. 2009, 24, 153-161. [CrossRef]

153. Long, D.; Wilcox, W.C.; Abrams, W.R.; Cohen, G.H.; Eisenberg, R.J. Disulfide bond structure of glycoprotein D of herpes simplex virus types 1 and 2. J. Virol. 1992, 66, 6668-6685. [CrossRef] [PubMed]

154. Heldwein, E.E.; Lou, H.; Bender, F.C.; Cohen, G.H.; Eisenberg, R.J.; Harrison, S.C. Crystal structure of glycoprotein B from herpes simplex virus 1. Science 2006, 313, 217-220. [CrossRef] 
155. Shukla, D.; Liu, J.; Blaiklock, P.; Shworak, N.W.; Bai, X.; Esko, J.D.; Cohen, G.H.; Eisenberg, R.J.; Rosenberg, R.D.; Spear, P.G. A novel role for 3-O-sulfated heparan sulfate in herpes simplex virus 1 entry. Cell 1999, 99, 13-22. [CrossRef]

156. Karasneh, G.A.; Shukla, D. Herpes simplex virus infects most cell types in vitro: Clues to its success. Virol. J. $2011,8,481$. [CrossRef]

157. Lee, G.E.; Murray, J.W.; Wolkoff, A.W.; Wilson, D.W. Reconstitution of herpes simplex virus microtubule-dependent trafficking in vitro. J. Virol. 2006, 80, 4264-4275. [CrossRef]

158. Lycke, E. Biological and molecular aspects on herpes simplex virus latency. Scand. J. Infect. Dis. Suppl. 1990, 69, $113-119$.

159. Hancock, M.H.; Corcoran, J.A.; Smiley, J.R. Herpes simplex virus regulatory proteins VP16 and ICP0 counteract an innate intranuclear barrier to viral gene expression. Virology 2006, 352, 237-252. [CrossRef] [PubMed]

160. McGeoch, D.J.; Rixon, F.J.; Davison, A.J. Topics in herpesvirus genomics and evolution. Virus Res. 2006, 117, 90-104. [CrossRef] [PubMed]

161. Steiner, I.; Kennedy, P.G.E. Herpes simplex virus latency in the nervous system-A new model. Neuropathol. Appl. Neurobiol. 1991, 17, 433-440. [CrossRef] [PubMed]

162. Everett, R.D. ICPO, a regulator of herpes simplex virus during lytic and latent infection. Bioessays 2000, 22, 761-770. [CrossRef]

163. Hadigal, S.R.; Agelidis, A.M.; Karasneh, G.A.; Antoine, T.E.; Yakoub, A.M.; Ramani, V.C.; Djalilian, A.R.; Sanderson, R.D.; Shukla, D. Heparanase is a host enzyme required for herpes simplex virus-1 release from cells. Nat. Commun. 2015, 6, 6985. [CrossRef]

164. Moore, M.D.; Bunka, D.H.J.; Forzan, M.; Spear, P.G.; Stockley, P.G.; Mcgowan, I.; James, W. Generation of neutralizing aptamers against herpes simplex virus type 2: Potential components of multivalent microbicides. J. Gen. Virol. 2011, 92, 1493-1499. [CrossRef]

165. Gopinath, S.C.B.; Hayashi, K.; Kumar, P.K.R. Aptamer that binds to the gD protein of herpes simplex virus 1 and efficiently inhibits viral entry. J. Virol. 2012, 86, 6732-6744. [CrossRef]

166. Yadavalli, T.; Agelidis, A.; Jaishankar, D.; Mangano, K.; Thakkar, N.; Penmetcha, K.; Shukla, D. Targeting herpes simplex virus-1 gD by a DNA aptamer can be an effective new strategy to curb viral infection. Mol. Ther. Nucleic Acids 2017, 9, 365-378. [CrossRef] [PubMed]

167. Bai, W.; Spivak, D.A. A double-imprinted diffraction-grating sensor based on a virus-responsive super-aptamer hydrogel derived from an impure extract. Angew. Chem. Int. Ed. 2014, 53, 2095-2098. [CrossRef]

168. Park, J.-W.; Lee, S.J.; Choi, E.-J.; Kim, J.; Song, J.-Y.; Gu, M.B. An ultra-sensitive detection of a whole virus using dual aptamers developed by immobilization-free screening. Biosens. Bioelectron. 2014, 51, 324-329. [CrossRef]

169. Roh, C.; Jo, S.K. Quantitative and sensitive detection of SARS coronavirus nucleocapsid protein using quantum dots-conjugated RNA aptamer on chip. J. Chem. Technol. Biotechnol. 2011, 86, 1475-1479. [CrossRef]

170. Moore, M.D.; Escudero-Abarca, B.I.; Suh, S.H.; Jaykus, L.-A. Generation and characterization of nucleic acid aptamers targeting the capsid P domain of a human norovirus GII. 4 strain. J. Biotechnol. 2015, 209, 41-49. [CrossRef] [PubMed]

171. Escudero-Abarca, B.I.; Suh, S.H.; Moore, M.D.; Dwivedi, H.P.; Jaykus, L.-A. Selection, characterization and application of nucleic acid aptamers for the capture and detection of human norovirus strains. PLoS ONE 2014, 9, e106805. [CrossRef] [PubMed]

172. Giamberardino, A.; Labib, M.; Hassan, E.M.; Tetro, J.A.; Springthorpe, S.; Sattar, S.A.; Berezovski, M.V.; DeRosa, M.C. Ultrasensitive norovirus detection using DNA aptasensor technology. PLoS ONE 2013, 8, e79087. [CrossRef] [PubMed]

173. Lee, S.J.; Kwon, Y.S.; Lee, J.-E.; Choi, E.-J.; Lee, C.-H.; Song, J.-Y.; Gu, M.B. Detection of VR-2332 strain of porcine reproductive and respiratory syndrome virus type II using an aptamer-based sandwich-type assay. Anal. Chem. 2013, 85, 66-74. [CrossRef] [PubMed]

174. Labib, M.; Zamay, A.S.; Berezovski, M.V. Multifunctional electrochemical aptasensor for aptamer clones screening, virus quantitation in blood and viability assessment. Analyst 2013, 138, 1865-1875. [CrossRef]

175. Labib, M.; Zamay, A.S.; Muharemagic, D.; Chechik, A.V.; Bell, J.C.; Berezovski, M.V. Aptamer-based viability impedimetric sensor for viruses. Anal. Chem. 2012, 84, 1813-1816. [CrossRef] [PubMed]

176. Labib, M.; Zamay, A.S.; Muharemagic, D.; Chechik, A.; Bell, J.C.; Berezovski, M.V. Electrochemical sensing of aptamer-facilitated virus immunoshielding. Anal. Chem. 2012, 84, 1677-1686. [CrossRef] [PubMed]

177. Wehbe, M.; Labib, M.; Muharemagic, D.; Zamay, A.S.; Berezovski, M.V. Switchable aptamers for biosensing and bioseparation of viruses (SwAps-V). Biosens. Bioelectron. 2015, 67, 280-286. [CrossRef] [PubMed]

178. Komorowska, B.; Hasiów-Jaroszewska, B.; Minicka, J. Application of nucleic acid aptamers for detection of Apple stem pitting virus isolates. Mol. Cell. Probes 2017, 36, 62-65. [CrossRef]

179. Xu, J.; Zhang, X.; Zhou, S.; Shen, J.; Yang, D.; Wu, J.; Li, X.; Li, M.; Huang, X.; Sealy, J.E.; et al. A DNA aptamer efficiently inhibits the infectivity of Bovine herpesvirus 1 by blocking viral entry. Sci. Rep. 2017, 7, 11796. [CrossRef] [PubMed]

180. Cnossen, E.J.; Silva, A.G.; Marangoni, K.; Arruda, R.A.; Souza, E.G.; Santos, F.A.; Fujimura, P.T.; Yokosawa, J.; Goulart, L.R.; Neves, A.F. Characterization of oligonucleotide aptamers targeting the 5'-UTR from dengue virus. Future Med. Chem. 2017, 9 , 541-552. [CrossRef]

181. Trausch, J.J.; Shank-Retzlaff, M.; Verch, T. Development and characterization of an HPV type-16 specific modified DNA aptamer for the improvement of potency assays. Anal. Chem. 2017, 89, 3554-3561. [CrossRef]

182. Li, P.; Zhou, L.; Wei, J.; Yu, Y.; Yang, M.; Wei, S.; Qin, Q. Development and characterization of aptamer-based enzyme-linked apta-sorbent assay for the detection of Singapore grouper iridovirus infection. J. Appl. Microbiol. 2016, 121, 634-643. [CrossRef] 
183. Lu, T.; Ma, Q.; Yan, W.; Wang, Y.; Zhang, Y.; Zhao, L.; Chen, H. Selection of an aptamer against Muscovy duck parvovirus for highly sensitive rapid visual detection by label-free aptasensor. Talanta 2018, 176, 214-220. [CrossRef]

184. Percze, K.; Szakács, Z.; Scholz, É.; András, J.; Szeitner, Z.; van den Kieboom, C.H.; Ferwerda, G.; de Jonge, M.I.; Gyurcsányi, R.E.; Mészáros, T. Aptamers for respiratory syncytial virus detection. Sci. Rep. 2017, 7, srep42794. [CrossRef] [PubMed]

185. Nilaratanakul, V.; Hauer, D.A.; Griffin, D.E. Development and characterization of sindbis virus with encoded fluorescent RNA aptamer Spinach2 for imaging of replication and immune-mediated changes in intracellular viral RNA. J. Gen. Virol. 2017, 98, 992-1003. [CrossRef] [PubMed]

186. Bell, C.L.; Yu, D.; Smolke, C.D.; Geall, A.J.; Beard, C.W.; Mason, P.W. Control of alphavirus-based gene expression using engineered riboswitches. Virology 2015, 483, 302-311. [CrossRef] [PubMed]

187. Cho, S.-J.; Woo, H.-M.; Kim, K.-S.; Oh, J.-W.; Jeong, Y.-J. Novel system for detecting SARS coronavirus nucleocapsid protein using an ssDNA aptamer. J. Biosci. Bioeng. 2011, 112, 535-540. [CrossRef] [PubMed]

188. Chen, H.-L.; Hsiao, W.-H.; Lee, H.-C.; Wu, S.-C.; Cheng, J.-W. Selection and characterization of DNA aptamers targeting all four serotypes of dengue viruses. PLOS ONE 2015, 10, e0131240. [CrossRef] [PubMed]

189. Gandham, S.H.A.; Volk, D.E.; Lokesh, G.L.R.; Neerathilingam, M.; Gorenstein, D.G. Thioaptamers targeting dengue virus type-2 envelope protein domain III. Biochem. Biophys. Res. Commun. 2014, 453, 309-315. [CrossRef]

190. Binning, J.M.; Wang, T.; Luthra, P.; Shabman, R.S.; Borek, D.M.; Liu, G.; Xu, W.; Leung, D.W.; Basler, C.F.; Amarasinghe, G.K. Development of RNA aptamers targeting Ebola virus VP35. Biochemistry 2013, 52, 8406-8419. [CrossRef] [PubMed]

191. Forrest, S.; Lear, Z.; Herod, M.R.; Ryan, M.; Rowlands, D.J.; Stonehouse, N.J. Inhibition of the foot-and-mouth disease virus subgenomic replicon by RNA aptamers. J. Gen. Virol. 2014, 95, 2649-2657. [CrossRef]

192. Punnarak, P.; Santos, M.D.; Hwang, S.D.; Kondo, H.; Hirono, I.; Kikuchi, Y.; Aoki, T. RNA aptamers inhibit the growth of the fish pathogen viral hemorrhagic septicemia virus (VHSV). Mar. Biotechnol. 2012, 14, 752-761. [CrossRef]

193. Hwang, S.D.; Midorikawa, N.; Punnarak, P.; Kikuchi, Y.; Kondo, H.; Hirono, I.; Aoki, T. Inhibition of hirame rhabdovirus growth by RNA aptamers. J. Fish Dis. 2012, 35, 927-934. [CrossRef]

194. Toscano-Garibay, J.D.; Benítez-Hess, M.L.; Alvarez-Salas, L.M. Targeting of the HPV-16 E7 protein by RNA aptamers. Methods Mol. Biol. 2015, 1249, 221-239. [CrossRef]

195. Leija-Montoya, A.G.; Benítez-Hess, M.L.; Toscano-Garibay, J.D.; Alvarez-Salas, L.M. Characterization of an RNA aptamer against HPV-16 L1 virus-like particles. Nucleic Acid Ther. 2014, 24, 344-355. [CrossRef]

196. Gourronc, F.A.; Rockey, W.M.; Thiel, W.H.; Giangrande, P.H.; Klingelhutz, A.J. Identification of RNA aptamers that internalize into HPV-16 E6/E7 transformed tonsillar epithelial cells. Virology 2013, 446, 325-333. [CrossRef] [PubMed]

197. Li, P.; Wei, S.; Zhou, L.; Yang, M.; Yu, Y.; Wei, J.; Jiang, G.; Qin, Q. Selection and characterization of novel DNA aptamers specifically recognized by Singapore grouper iridovirus-infected fish cells. J. Gen. Virol. 2015, 96, 3348-3359. [CrossRef] [PubMed]

198. Li, P.; Yan, Y.; Wei, S.; Wei, J.; Gao, R.; Huang, X.; Huang, Y.; Jiang, G.; Qin, Q. Isolation and characterization of a new class of DNA aptamers specific binding to Singapore grouper iridovirus (SGIV) with antiviral activities. Virus Res. 2014, 188, 146-154 [CrossRef] [PubMed]

199. Beier, R.; Pahlke, C.; Quenzel, P.; Henseleit, A.; Boschke, E.; Cuniberti, G.; Labudde, D. Selection of a DNA aptamer against norovirus capsid protein VP1. FEMS Microbiol. Lett. 2014, 351, 162-169. [CrossRef]

200. Liang, H.-R.; Hu, G.-Q.; Xue, X.-H.; Li, L.; Zheng, X.-X.; Gao, Y.-W.; Yang, S.-T.; Xia, X.-Z. Selection of an aptamer against rabies virus: A new class of molecules with antiviral activity. Virus Res. 2014, 184, 7-13. [CrossRef]

201. Liang, H.-R.; Hu, G.-Q.; Li, L.; Gao, Y.-W.; Yang, S.-T.; Xia, X.-Z. Aptamers targeting rabies virus-infected cells inhibit street rabies virus in vivo. Int. Immunopharmacol. 2014, 21, 432-438. [CrossRef]

202. Liang, H.-R.; Liu, Q.; Zheng, X.-X.; Gai, W.-W.; Xue, X.-H.; Hu, G.-Q.; Wu, H.-X.; Wang, H.-L.; Yang, S.-T.; Xia, X.-Z. Aptamers targeting rabies virus-infected cells inhibit viral replication both in vitro and in vivo. Virus Res 2013, 173, 398-403. [CrossRef] [PubMed]

203. Liang, H.-R.; Hu, G.-Q.; Zhang, T.; Yang, Y.-J.; Zhao, L.-L.; Qi, Y.-L.; Wang, H.-L.; Gao, Y.-W.; Yang, S.-T.; Xia, X.-Z. Isolation of ssDNA aptamers that inhibit rabies virus. Int. Immunopharmacol. 2012, 14, 341-347. [CrossRef]

204. Ellenbecker, M.; Sears, L.; Li, P.; Lanchy, J.-M.; Lodmell, J.S. Characterization of RNA aptamers directed against the nucleocapsid protein of rift valley fever virus. Antivir. Res. 2012, 93, 330-339. [CrossRef] [PubMed]

205. Ndongwe, T.P.; Adedeji, A.O.; Michailidis, E.; Ong, Y.T.; Hachiya, A.; Marchand, B.; Ryan, E.M.; Rai, D.K.; Kirby, K.A.; Whatley, A.S.; et al. Biochemical, inhibition and inhibitor resistance studies of xenotropic murine leukemia virus-related virus reverse transcriptase. Nucleic Acids Res. 2012, 40, 345-359. [CrossRef] [PubMed]

206. Schütze, T.; Wilhelm, B.; Greiner, N.; Braun, H.; Peter, F.; Mörl, M.; Erdmann, V.A.; Lehrach, H.; Konthur, Z.; Menger, M.; et al. Probing the SELEX process with next-generation sequencing. PLoS ONE 2011, 6, e29604. [CrossRef] [PubMed]

207. Eulberg, D.; Buchner, K.; Maasch, C.; Klussmann, S. Development of an automated in vitro selection protocol to obtain RNA-based aptamers: Identification of a biostable substance P antagonist. Nucleic Acids Res. 2005, 33, e45. [CrossRef] [PubMed]

208. Blind, M.; Blank, M. Aptamer selection technology and recent advances. Mol. Ther. Nucleic Acids 2015, 4, e223. [CrossRef] [PubMed]

209. Sabri, M.Z.; Hamid, A.A.A.; Hitam, S.M.S.; Rahim, M.Z.A. In-silico selection of aptamer: A review on the revolutionary approach to understand the aptamer design and interaction through computational chemistry. Mater. Today Proc. 2019, 19, 1572-1581. [CrossRef] 
210. Chushak, Y.; Stone, M.O. In silico selection of RNA aptamers. Nucleic Acids Res. 2009, 37, e87. [CrossRef]

211. Saliva-Based COVID-19 DNA Aptamer Test: Formative Usability and Internal Validation Study. Available online: https: //clinicaltrials.gov/ct2/show/NCT04974203 (accessed on 20 August 2021).

212. Yang, G.; Li, Z.; Mohammed, I.; Zhao, L.; Wei, W.; Xiao, H.; Guo, W.; Zhao, Y.; Qu, F.; Huang, Y. Identification of SARS-CoV-2against aptamer with high neutralization activity by blocking the RBD domain of spike protein 1 . Signal Transduct. Target Ther. 2021, 6, 227. [CrossRef]

213. Schmitz, A.; Weber, A.; Bayin, M.; Breuers, S.; Fieberg, V.; Famulok, M.; Mayer, G. A SARS-CoV-2 spike binding DNA aptamer that inhibits pseudovirus infection by an RBD-independent mechanism. Angew. Chem. Int. Ed. 2021, 60, 10279-10285. [CrossRef]

214. Pramanik, A.; Gao, Y.; Patibandla, S.; Mitra, D.; McCandless, M.G.; Fassero, L.A.; Gates, K.; Tandon, R.; Ray, P.C. Aptamer conjugated gold nanostar-based distance-dependent nanoparticle surface energy transfer spectroscopy for ultrasensitive detection and inactivation of corona virus. J. Phys. Chem. Lett. 2021, 12, 2166-2171. [CrossRef]

215. Ando, T.; Yamamoto, M.; Takamori, Y.; Tsukamoto, K.; Fuji, D.; Kawakami, T. In vitro selection of an RNA aptamer yields an interleukin-6/interleukin-6 receptor interaction inhibitor. Biosci. Biotechnol. Biochem. 2021, 85, 1170-1174. [CrossRef] [PubMed] 